\title{
Differential somatic cell count as an additional indicator for intramammary infections in dairy cows
}

\author{
C. Kirkeby, ${ }^{1,2 *}$ ․ N. Toft, ${ }^{2}$ D. Schwarz, ${ }^{3} \odot$ M. Farre, ${ }^{4} \odot$ S. S. Nielsen, ${ }^{1} \oplus$ L. Zervens, ${ }^{2}$ S. Hechinger, ${ }^{5}$ \\ and T. Halasa ${ }^{1,2}$ (1) \\ ${ }^{1}$ Department of Veterinary and Animal Sciences, Faculty of Health and Medical Sciences, University of Copenhagen, 1870 Frederiksberg, \\ Denmark \\ ${ }^{2}$ Division for Diagnostics and Scientific Advice, National Veterinary Institute, Technical University of Denmark, 2800 Kgs. Lyngby, Denmark \\ ${ }^{3}$ Foss Analytical A/S, 3400 Hillerød, Denmark \\ ${ }^{4}$ SEGES Livestock Innovation, 8200 Aarhus, Denmark \\ ${ }^{5}$ Landesbetrieb Hessisches Landeslabor (LHL), 35392 Gießen, Germany
}

\section{ABSTRACT}

Mastitis, often caused by intramammary infection (IMI), is a significant problem in dairy farming globally. Somatic cell count (SCC) is widely used as a parameter for screening IMI in cows that are then treated or culled. We investigated the potential of a new parameter, differential SCC (DSCC), to detect IMI at cow level when SCC is already known. We achieved this using bacterial culture (BC) and PCR to detect 4 categories of pathogens (major, minor, other, and any) in 2 Danish dairy herds. Quarter milk samples were collected from monthly dairy herd improvement samplings over $1 \mathrm{yr}$ and analyzed with $\mathrm{BC}$, whereas cowlevel dairy herd improvement samples were analyzed using PCR. Days in milk, parity, and IMI status had a significant effect on DSCC. Using DSCC in addition to SCC significantly improved the indication of IMI compared with using only SCC in the any pathogen category in both herds as well as the minor pathogens category in herd 2 when BC was used for detection. When PCR was used to detect IMI, the use of DSCC in addition to SCC was significant for the other pathogens category in herd 1 and the minor pathogens category in herd 2. Thus, our data revealed that DSCC can add significant information describing IMI status even when SCC is already known; however, this depends on the causative pathogen. Future studies may address how to use DSCC in practice as well as consider the availability of temporal data to potentially gain insight into the course of infection.

Key words: dairy cow, differential somatic cell count, mastitis

Received February 21, 2019.

Accepted October 4, 2019.

*Corresponding author: ckir@sund.ku.dk

\section{INTRODUCTION}

Mastitis, often caused by IMI, is a major problem in dairy herds worldwide, causing considerable economic losses (Halasa et al., 2007). Furthermore, IMI is a predominant reason for antibiotic use in dairy production and can impair animal welfare (von Keyserlingk et al., 2009). Intramammary infections are predominantly triggered by infection with bacteria such as Staphylococcus aureus, Streptococcus spp., and coliforms (e.g., Schwarz et al., 2010). In response to an IMI, the udder attracts white blood cells to fight and clear the bacteria, leading to an elevation in the milk SCC (Sordillo and Streicher, 2002; Schukken et al., 2003; Wall et al., 2018). The SCC reflects the inflammatory response to infection and is widely used to monitor and manage udder health at quarter, cow, and herd levels and is typically measured monthly using DHI samples from milk recording schemes (Schukken et al., 2003; Jones, 2009).

The utility of SCC in monitoring udder health has been studied intensively, and thresholds to distinguish between uninfected and infected quarters have been suggested, including recommendations for the use of repeated SCC measurements (e.g., Schepers et al., 1997; Schukken et al., 2003; IDF, 2013). However, neither the sensitivity nor the specificity of these thresholds for indicating IMI are optimal (Schukken et al., 2003).

Differential SCC (DSCC) has recently been described as a new tool for monitoring udder health (Schwarz et al., 2011; Aref et al., 2018; Wall et al., 2018), and the methodology for simultaneous determination of SCC and DSCC has been published (Damm et al., 2017). The DSCC as used in this study targets the 3 main types of immune cells in milk: polymorphonuclear neutrophils (PMN), lymphocytes, and macrophages. Specifically, DSCC represents the percentage of PMN combined with lymphocytes, as described in detail by Damm et al. (2017). Consequently, the percentage 
of macrophages can be calculated by subtracting the DSCC from 100. Different cell types respond differently to IMI over time, and it is not possible to investigate this using SCC, which represents only the total number of cells (Pillai et al., 2001; Schwarz et al., 2011; Pilla et al., 2013). For instance, a predominance of PMN indicates a response to IMI at an early stage of the infection (Schwarz et al., 2011). Lymphocytes and macrophages, on the other hand, trigger PMN recruitment, but their numbers tend to be low during inflammation (Sordillo and Streicher, 2002). As a result, DSCC could help characterize the IMI status. This may aid decision making in terms of segregation, treatment with antibiotics, or culling of cows with udder health problems.

Given the novelty of the parameter, the basic characterization of DSCC in cow-composite samples and its potential for indicating IMI have yet to be described. The objectives of this study were therefore to (1) quantify the factors affecting DSCC and (2) evaluate whether DSCC can improve IMI detection significantly when SCC is already known.

\section{MATERIALS AND METHODS}

\section{Herds}

Two herds were enrolled in this study, as described in detail elsewhere (Kirkeby et al., 2019). Briefly, both herds had Holstein-Friesian cows in freestalls with a side-by-side milking parlor. Herd 1 was known to have problems with major pathogens, whereas herd 2 did not have many issues relating to major pathogens. Herd 1 consisted of 174 to 183 lactating cows that were milked twice daily, and herd 2 had 334 to 396 lactating cows that were milked 3 times per day (Kirkeby et al., 2019). The bulk milk SCC in herd 1 was on average 294,000 cells $/ \mathrm{mL}$ in the study period, whereas the bulk milk SCC in herd 2 was on average 280,000 cells $/ \mathrm{mL}$. In this longitudinal study, all lactating cows from both herds were sampled once a month for a period of 1 yr starting in early 2017.

\section{Sampling and Laboratory Analyses}

Sampling is also described in detail elsewhere (Kirkeby et al., 2019). Both quarter foremilk and cow-composite samples were collected. Briefly, quarter foremilk samples for bacterial culture (BC) were taken following cleaning and disinfection of the teats from all lactating cows on 12 sampling dates over $1 \mathrm{yr}$ in accordance with National Mastitis Council standards (Oliver et al., 2004). Cow-composite samples were taken using TruTest milk meters (Tru-Test, Auckland, New Zealand) at cow level. All samples were then kept in thermally insulated boxes with cooling elements during transport to the laboratory. The SCC and DSCC measurements on all quarter foremilk and cow-composite samples were obtained using a Fossomatic 7 DC (Foss, Hillerød, Denmark). All cow-composite samples were preserved with $0.5 \%$ bronopol, whereas quarter foremilk samples were preserved with boric acid. Analyses of BC and PCR were performed within $48 \mathrm{~h}$ of sample collection. The PCR analyses were done on cow-composite samples using a DNA Diagnostic M4BDF kit (DNA Diagnostic, Risskov, Denmark; Bennedsgaard et al., 2016). This kit can detect Staphylococcus aureus, Streptococcus agalactiae, Streptococcus uberis, Streptococcus dysgalactiae, Escherichia coli, Mycoplasma bovis, Mycoplasma spp., $\beta$-lactamase, CNS, Prototheca spp., Klebsiella spp., Enterococcus spp., and Lactococcus lactis. We considered cycle threshold values $<37$ to be positive in accordance with the manufacturer's recommendations.

\section{Data}

Even though the BC samples were recorded at quarter level, the results were combined for each cow so that if 1 quarter was infected with a specific pathogen, the cow was registered as infected with that pathogen at the time of sampling. This was done to standardize all data at cow level. The IMI status of each quarter was defined according to pathogens obtained from $\mathrm{BC}$ or PCR and categorized into groups reflecting major and minor pathogens (Reneau, 1986; Schwarz et al., 2010), as presented in Table 1 . In addition, we created a group of other pathogens that are traditionally not included in either of the 2 previous groups. The pathogen groups were mutually exclusive (Table 1). However, because many cows had more than 1 pathogen at any given time, it was not possible to assign the cows to mutually exclusive pathogen groups. We therefore divided the cow-level records into 4 pathogen groups: (1) healthy cows with only negative BC or PCR results for all quarters on the test day; (2) cows that did not have any minor or major pathogens recorded in any quarters on the test day but did have 1 or more quarters with a pathogen from the "other" category; (3) cows that had pathogens from the "minor" category-they had no major pathogens recorded in any quarters on the test day but could have had pathogens from the "other" category recorded; and (4) cows that were positive for a major pathogen, including coliforms, on the test day but could also have had IMI with less severe pathogens from the "minor" or "other" categories (see Table 1 for category definitions). Records with no IMI were used in combination with data from each of the pathogen groups in the analyses. Furthermore, we considered infections in general in the "any pathogen" group, whereby cows 
Table 1. The pathogens identified in the bacterial culture (BC) and PCR analyses

\begin{tabular}{|c|c|c|c|}
\hline $\begin{array}{l}\text { Pathogen } \\
\text { group }\end{array}$ & Pathogen & $\mathrm{BC}$ & PCR \\
\hline \multirow[t]{8}{*}{ Major } & Staphylococcus aureus & $x$ & $\times$ \\
\hline & Streptococcus agalactiae & $x$ & $x$ \\
\hline & Streptococcus uberis & $x$ & $x$ \\
\hline & Streptococcus dysgalactiae & $x$ & $\times$ \\
\hline & Escherichia coli & $x$ & $\times$ \\
\hline & Klebsiella pneumoniae & $x$ & $x$ \\
\hline & Citrobacter freundii & $x$ & \\
\hline & Citrobacter sp. & $\times$ & \\
\hline \multirow[t]{2}{*}{ Minor } & Corynebacterium sp. & $x$ & \\
\hline & CNS & $x$ & $x$ \\
\hline \multirow[t]{17}{*}{ Other } & Aerococcus viridans & $x$ & \\
\hline & Aerococcus sp. & $x$ & \\
\hline & Enterococcus casseliflavus & $\times$ & \\
\hline & Enterococcus sp. & $\times$ & $x$ \\
\hline & Streptococcus mitis & $x$ & \\
\hline & Streptococcus lutetiensis & $x$ & \\
\hline & Streptococcus salivarius & $x$ & \\
\hline & Streptococcus sanguinis & $\times$ & \\
\hline & Streptococcus sp. & $\times$ & \\
\hline & Esculin-positive Streptococcus & $\times$ & \\
\hline & Lactococcus sp. & $x$ & \\
\hline & Candida tropicalis & $\times$ & \\
\hline & Pasteurella multocida & $x$ & \\
\hline & Micrococcus luteus & $\times$ & \\
\hline & Mycoplasma bovis & & $\times$ \\
\hline & Mycoplasma sp. & & $x$ \\
\hline & Prototheca sp. & & $x$ \\
\hline
\end{tabular}

were regarded as infected if any pathogen was detected in any of the quarters.

The inclusion criteria for records were (1) SCC should be within performance range (i.e., between 50,000 and 1,500,000 cells/mL; Damm et al., 2017), (2) a sample was considered contaminated if it had $>3$ pathogens, and (3) DIM should be $<600$. We deliberately decided to include only records within this specified performance range given the uncertainty of results outside this range. In particular, DSCC in samples $<50,000$ cells/mL can vary drastically (Damm et al., 2017) and would thus potentially lead to incorrect conclusions.

\section{Statistical Analyses}

Data for SCC were log-transformed before analysis to better accommodate the underlying assumptions of linear mixed models. Data for DIM, SCC, and DSCC were normalized to a scale between 0 and 1 by dividing the measured value with the largest value in the herd. All statistical analyses were stratified by herd and detection method (BC or PCR) separately.

Factors Affecting DSCC. First, we explored the characteristics of DSCC in relation to relevant parameters. We created regression models separately for each herd using the "lmer" function with a log link in R (R Core Team, 2015) using the nlme package (Pinheiro et al., 2018). Differential SCC was used as the dependent variable in a mixed-effect model with a random effect of cow and relevant independent variables:

$$
\begin{aligned}
\operatorname{DSCC}_{i j k}= & \beta_{0}+\beta_{1} \text { Path }_{k}+\beta_{2} \operatorname{DIM}_{i j}+\beta_{3} \mathrm{DIM}_{i j}^{2} \\
& +\beta_{4} \mathrm{PAR}_{i j}+\text { Cow }_{i}+\varepsilon_{i j k},
\end{aligned}
$$

where $i$ denotes cow, $j$ denotes sample, Path $_{k}$ describes infection with pathogen group $k$ (or any pathogen), $\mathrm{DIM}^{2}$ is the second-order term of DIM, PAR is parity (grouped in 1,2 , or $\geq 3$ ), Cow is the random effect of each cow, and $\varepsilon$ is the error term. Cow was introduced as a random effect to allow the intercept $\left(\beta_{0}\right)$ to vary for each cow. $\beta 1$ to $\beta 4$ denote the estimated coefficients for each variable. Before the analyses were complete, we inspected the data for each cow with a semi-variogram to visually inspect whether any temporal correlation was present (Pinheiro et al., 2018). We found no indication of a substantial temporal effect between measurements for each cow, and therefore we did not introduce an autocorrelative effect. We used backward elimination with ANOVA testing $(P=0.05)$ to choose variables to include in the final model, attempting to exclude DIM ${ }^{2}$, DIM, PAR, and Path, in that order, for both tests and herds.

For an overview of how the DSCC values behaved for different parities, we fitted the density distribution of DSCC per lactation for each of the herds. We also plotted the DSCC values over DIM for each herd and pathogen group to observe whether there was a general trend in the DSCC over time.

$D S C C$ as an Indicator of IMI. In the second analysis, we constructed generalized linear mixed models using the "glmer" function in the R package "lme4" (Bates et al., 2015) to evaluate the use of DSCC. The aim was to compare the performance of models that included SCC, DSCC, or both with a baseline model and thereby evaluate their potential for indicating IMI. We explored 4 models:

$$
\begin{aligned}
& \operatorname{Logit}\left[\operatorname{Pr}\left(\operatorname{Path}_{k}=1\right)\right]=\beta_{0}+\beta_{1} \operatorname{DIM}_{i j k} \\
& +\beta_{4} \mathrm{PAR}_{i}+\mathrm{Cow}_{i} \\
& \operatorname{Logit}\left[\operatorname{Pr}\left(\operatorname{Path}_{k}=1\right)\right]=\beta_{0}+\beta_{1} \operatorname{DSCC}_{i j k} \\
& +\beta_{2} \mathrm{DIM}_{i j k}+\beta_{3} \mathrm{PAR}_{i}+\text { Cow }_{i} \\
& \operatorname{Logit}\left[\operatorname{Pr}\left(\operatorname{Path}_{k}=1\right)\right]=\beta_{0}+\beta_{1} \operatorname{logSCC} C_{i j k} \\
& +\beta_{2} \mathrm{DIM}_{i j k}+\beta_{3} \mathrm{PAR}_{i}+\mathrm{Cow}_{i} \\
& \operatorname{Logit}\left[\operatorname{Pr}\left(\operatorname{Path}_{k}=1\right)\right]=\beta_{0}+\beta_{1} \operatorname{logSCC} C_{i j k}+\beta_{2} \mathrm{DSCC}_{i j k} \\
& +\beta_{3} \mathrm{DIM}_{i j k}+\beta_{4} \mathrm{PAR}_{i}+\mathrm{Cow}_{i},
\end{aligned}
$$


where $i$ denotes cow, $j$ denotes sample, Path $_{k}$ denotes infection status with pathogen group $k$ (or any pathogen), and Cow denotes the random effect of each cow. Model 2a (Equation 2a) is our baseline model, model 2b (Equation 2b) includes DSCC, model 2c (Equation 2c) includes SCC, and model 2d (Equation 2d) includes both DSCC and SCC. Confidence intervals for the estimated coefficients were found using bootstrapping with the "confint" function in R (R Core Team, 2015). We used the likelihood ratio test in the "anova" function in base $\mathrm{R}$ to test whether model $2 \mathrm{~d}$, which includes DSCC, explained significantly more of the variation in IMI status compared with model 2c, which does not include DSCC.

To test the performance of each of the 4 models (for each herd and detection method), we bootstrapped the data by randomly subsampling $80 \%$ of the records and then created the mixed-effect models (Equations 2a-d) from this subset using the resulting model for the last $20 \%$ of the data. This was also done for each herd and IMI detection method. We then used a receiver operating characteristic (ROC) curve with associated area under the curve (AUC; pROC package in R; Robin et al., 2011) to estimate the accuracy of each model. The AUC is a measure of the model accuracy, where the value 0.5 corresponds to random classification of infection status and 1 corresponds to perfect classification of infection (Pyörälä, 2003). We repeated this bootstrap ROC analysis 250 times (deemed sufficient in a convergence analysis; data not shown) to obtain a distribution of AUC measures to indicate the performance of the models (Equations 2a-d). We then used the median of this distribution to compare the models. We compared models 2c and 2d (Equations 2c and d) in an ROC test for each of the 250 repetitions (DeLong et al., 1988) to test whether including DSCC in the model would explain more of the variation in the data compared with including only SCC. In this way, we compared a situation in which only SCC is used to indicate IMI with a situation in which both SCC and DSCC are used. If the models performed significantly better when DSCC was added, this means that indication of IMI is significantly improved by including DSCC in the model. This resulted in a distribution of $250 \mathrm{P}$-values, from which we used the proportion of significant outcomes to indicate whether the models generally performed significantly better when adding DSCC to the equation.

\section{RESULTS}

\section{Data}

An overview of the data cleaning process is shown in the flow diagram in Figure 1. Initially, 2,132 cow- composite samples were obtained from herd 1. Of these, 1,297 had an SCC measure within the performance range (743 and 92 samples had SCC $<50,000$ and $>1,500,000$ cells $/ \mathrm{mL}$, respectively). In total, 75 additional samples were removed from the herd 1 data because the Fossomatic 7 DC instrument was running out of specifications when these samples were analyzed. This resulted in 1,222 records, 44 of which were excluded due to contamination ( $>3$ different pathogens). Of the remaining 1,178 records, 36 had no DIM information, and another 6 had contaminating flora directly registered by the laboratory in the BC result. Finally, 3 samples from cows with DIM $>600$ were also excluded, leaving 1,133 records from herd 1 included in the analysis. For the PCR analyses, an additional 39 records were removed due to contamination ( $>3$ pathogens detected by PCR).

For herd 2, there were initially 4,336 cow-composite records, of which 3,006 were within the DSCC performance range $(1,216$ and 114 samples had $\mathrm{SCC}<50,000$ and $>1,500,000$ cells $/ \mathrm{mL}$, respectively). Of these, 200 records had to be excluded due to the Fossomatic 7 DC instrument running out of specifications. Of the remaining 2,806 records, 78 were excluded due to contamination with 3 or more recorded pathogens. A further 14 samples did not have a DIM record and were excluded. Of the remaining 2,712 records, 11 had contaminating flora and were excluded. Finally, 5 of these records had DIM >600 and were excluded, leaving 2,696 records from herd 2. For the PCR analyses, an additional 34 records were removed due to contamination ( $>3$ pathogens detected by PCR).

Descriptive Statistics. The occurrence and distribution of pathogens for herds 1 and 2 are shown in Table 2. The prevalence (determined by either BC or PCR) of major pathogen IMI was higher in herd 1 than in herd 2. In herd 1 , using $\mathrm{BC}$, we found $80,14,1$, and $5 \%$ of cows infected with major, minor, or other pathogens and uninfected cows, respectively. Using PCR in herd 1 , we found $50,2,11$, and $37 \%$, respectively. In herd 2, using $\mathrm{BC}$ we found $9,82,1$, and $8 \%$ of cows infected with major, minor, or other pathogens and uninfected cows, respectively. Using PCR, we found $12,16,23$, and 50\%, respectively. Differential SCC and SCC were positively associated for the cows within each pathogen group (Figure 2). In herd 1, Pearson correlation coefficient was $0.46,0.47,0.55$, and 0.30 between SCC and DSCC for cows infected with major, minor, or other pathogens and uninfected cows, respectively. In herd 2 , these coefficients were $0.52,0.42,0.45$, and 0.41 , respectively. The mean SCC for herd 1 was higher for samples with IMI caused by other pathogens when using both BC and PCR compared with IMI caused by minor and major pathogens (Table 2). In herd 2, the 


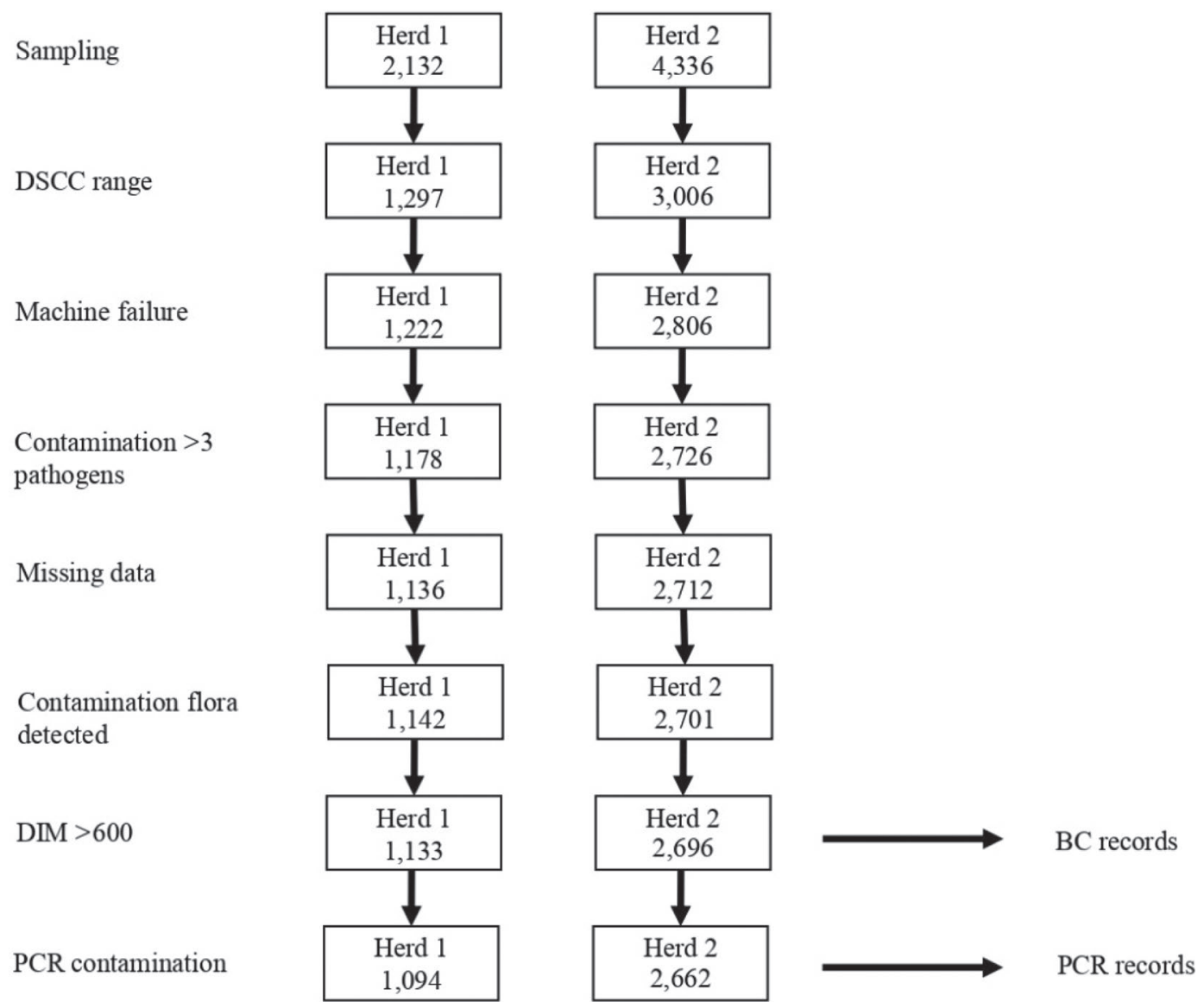

Figure 1. Flow diagram of the data cleaning process. Differential SCC (DSCC) consists of the numbers of polymorphonuclear neutrophils $(\mathrm{PMN})$, lymphocytes, and macrophages and describes the percentage of PMN and lymphocytes among these. BC $=$ bacterial culture.

mean SCC was highest for major pathogens compared with the other pathogen groups. This was also true for the DSCC in herd 2 but not in herd 1, where DSCC was highest in the other pathogen IMI group. Differential SCC generally decreased with increasing DIM (Figure 3).

In both herds, DSCC seemed more stable among lactations than SCC, judged visually (Figure 4). Both parameters loosely resembled a gamma distribution, but SCC had a fat tail (representing extreme values) pointing upward, whereas DSCC had a fat tail pointing downward. The distributions showed more pronounced peaks in the middle for higher parities, which is likely to be a consequence of having fewer records.

Factors Affecting DSCC. The SCC increased with increasing parity (Figure 5). The DSCC decreased slightly with increasing DIM, with a slight increase at the beginning of the lactation, similar to a lactation curve but with a smaller increase at the beginning (Figure 3). Days in milk, parity, and pathogen group were associated with DSCC when using both BC and PCR (Table 3).
Results of the mixed-effect models for herds 1 and 2 using BC and PCR are presented in Table 3. When using $\mathrm{BC}$ for herd 1, the DSCC was higher for other pathogens than for major pathogens and smallest for minor pathogens. When using BC for herd 2, all 3 pathogen types had a similar effect on the DSCC (Table 3). When using PCR, major pathogens had the largest effect on the DSCC in both herds compared with the other groups. Minor and other pathogens had a negative effect in herd 1. A small negative effect was also found for other pathogens when PCR was used in herd 2, and a positive effect was found for minor and major pathogens (Table 3). Parity was negatively associated with DSCC, as this was lower for parity 2 and $3+$ for both BC and PCR. However, in herd 2, parity had a positive effect at parity 2 for $\mathrm{BC}$ and at parity $3+$ for both BC and PCR (Table 3 ).

$D S C C$ as an Indicator of IMI. The results from the $\mathrm{BC}$ test in herd 1 showed that DSCC contributed significantly to indicating any pathogen but not specific pathogen groups (Table 4). The model for other pathogens could not converge due to a small number 
Table 2. The number of records in each pathogen group detected using bacterial culture (BC) and PCR in 2 Danish dairy herds as well as descriptive statistics ${ }^{1}$

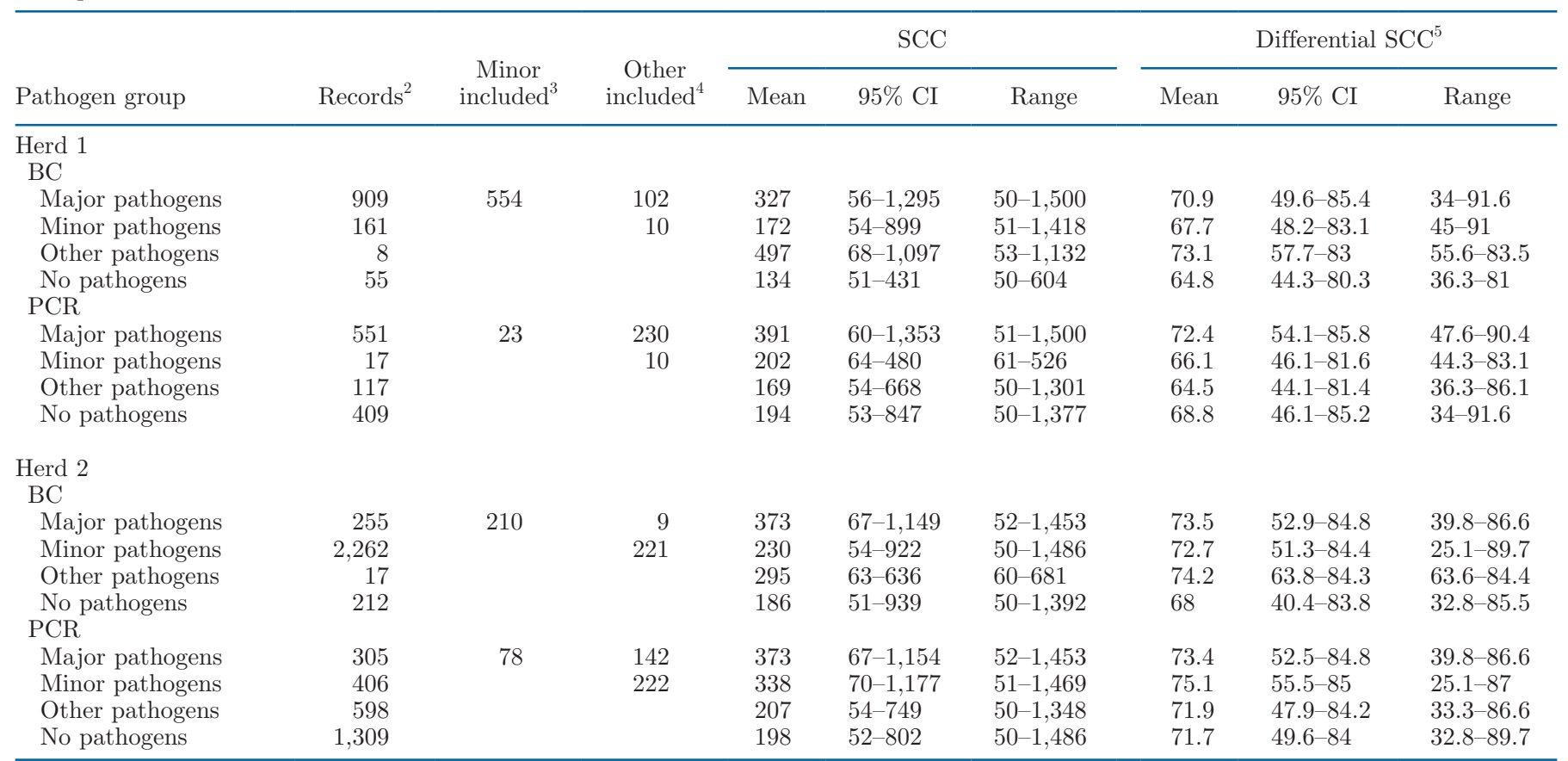

${ }^{1}$ All SCC values are given in 1,000 cells $/ \mathrm{mL}$.

${ }^{2}$ Number of records for each group.

${ }^{3}$ Number of minor pathogen records that are included in the records due to multiple infections per cow.

${ }^{4}$ Number of other pathogen records that are included in the records due to multiple infections per cow.

${ }^{5}$ Consists of the number of polymorphonuclear neutrophils (PMN), lymphocytes, and macrophages and describes the percentage of PMN and lymphocytes among these.

of records. The proportion of ROC tests, out of the 250 bootstrap iterations, where DSCC was found to contribute significantly was about $5 \%$ for major pathogens, $2 \%$ for minor pathogens, and $28 \%$ for any pathogens when using $\mathrm{BC}$ in herd 1 (Table 4). In the ROC analyses, the median AUC values were very similar for any pathogens at a level of 0.71 to 0.76 across the 4 models.

Using the PCR results for herd 1, DSCC significantly improved the model only for other pathogens (Table 4). The proportion of ROC tests with significant results was $42 \%$ for major pathogens, only about $3 \%$ for other pathogens, and $20 \%$ for any pathogens (Table 4).

For herd 2, the BC results showed that DSCC was significant for indicating minor pathogens and any pathogens (Table 4). The proportion of ROC tests that were significant was highest for any pathogens at $80 \%$. Using both SCC and DSCC, the median AUC was highest for major pathogens at $89 \%$, then $75 \%$ for minor pathogens, $76 \%$ for other pathogens, and $60 \%$ for any pathogens.

The PCR results from herd 2 showed that adding DSCC to the model gave a significant result for major and minor pathogens (Table 4). The proportion of ROC tests for which DSCC added significant information for major, minor, other, and any pathogens was $28,60,7$, and $13 \%$, respectively (Table 4 ). The AUC values were generally similar when comparing $\mathrm{BC}$ and $\mathrm{PCR}$ for herd 2. The lowest AUC was found for other pathogens, with a median of 0.52 , even when using both SCC and DSCC. The highest AUC when using both SCC and DSCC was 0.83 for major pathogens.

The smoothed density distributions of DSCC (Figure 4) showed a considerable overlap between the distributions for each parity, with a slight tendency to increase at higher parities. There was a more pronounced tendency for SCC to increase at higher parities, meaning that DSCC was more stable over the parities than SCC. Furthermore, the DSCC distributions revealed a tendency for a lower tail, whereas the SCC revealed a tendency for an upper tail, which could indicate that the dynamics in the 2 measures were different.

In both herds, DSCC tended to decrease over the lactation period, whereas SCC increased with increasing parity (Figure 5). In the bootstrapping analysis, we evaluated the performance of 250 different models of each of the 4 model types for each herd and test. Figures 6 and 7 present the resulting distributions of 
Herd 1: Major pathogens

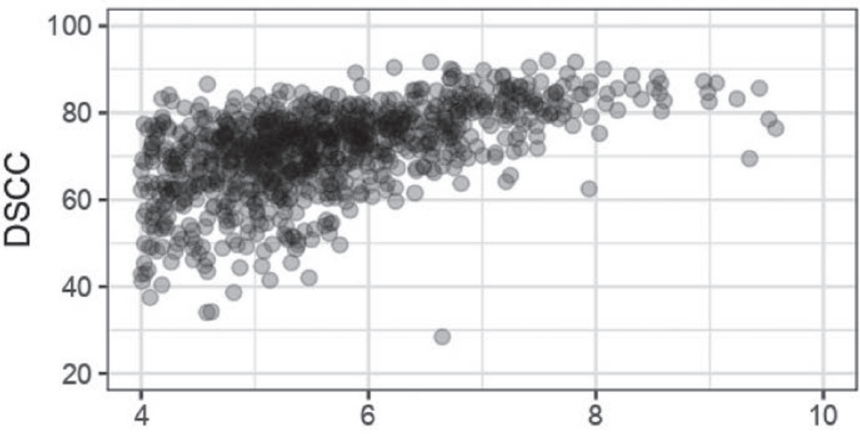

Herd 1: Other pathogens

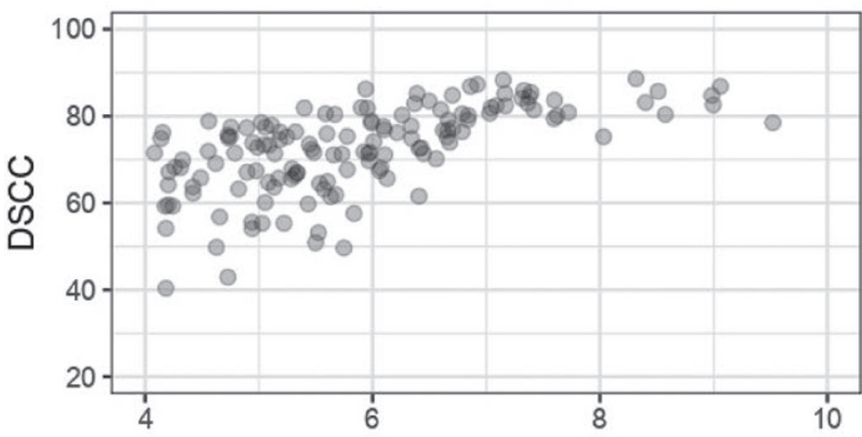

Herd 2: Major pathogens

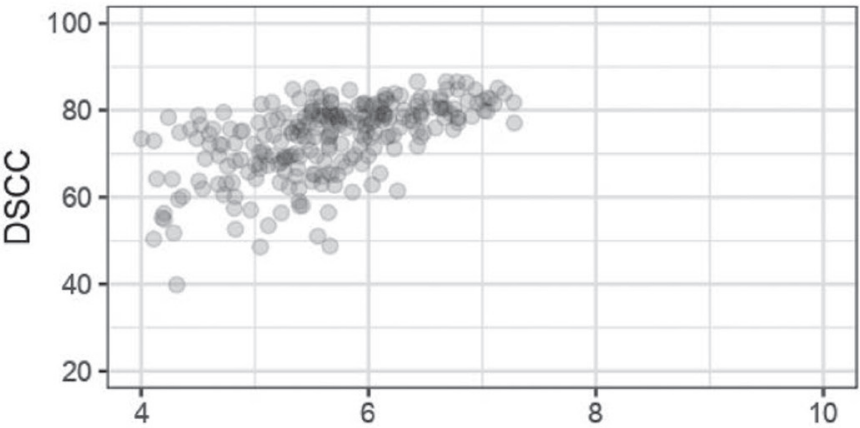

Herd 2: Other pathogens

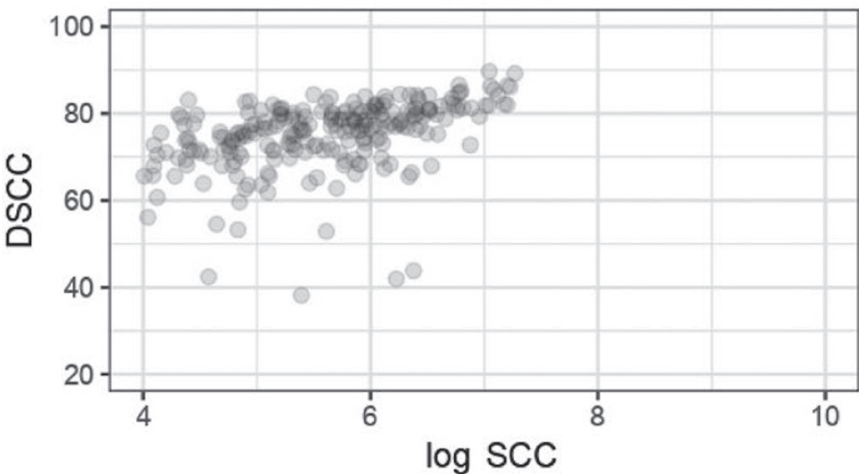

Herd 1: Minor pathogens

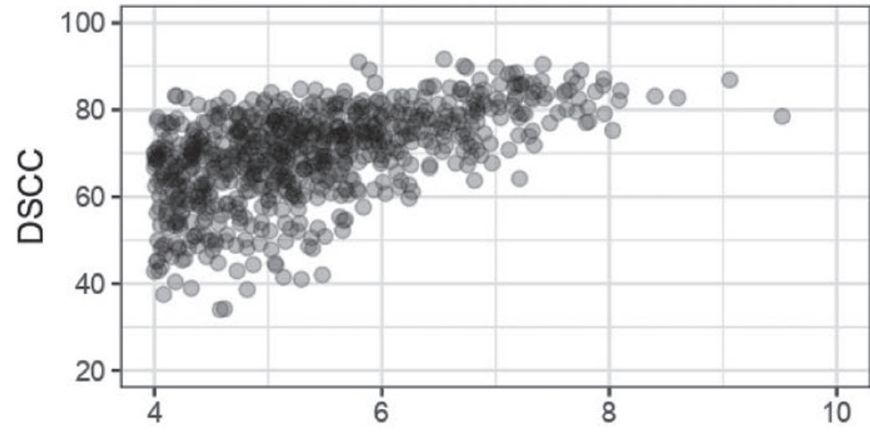

Herd 1: No pathogens

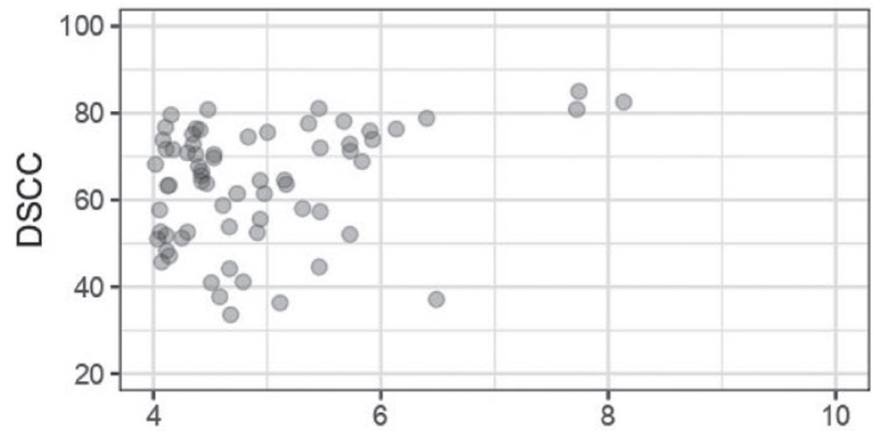

Herd 2: Minor pathogens

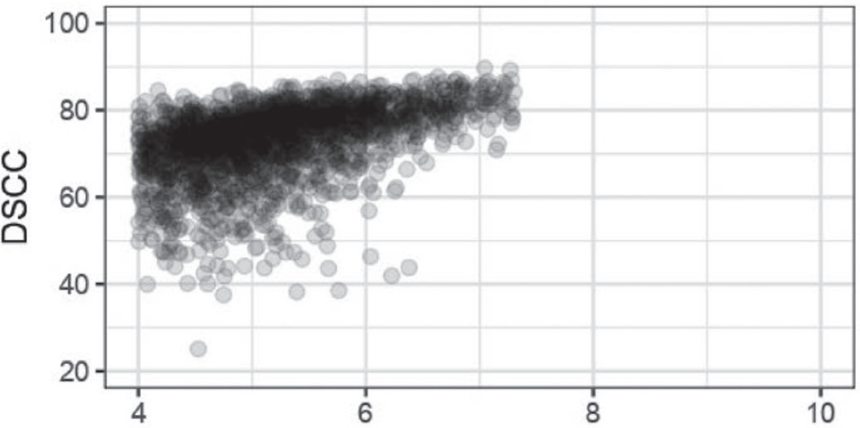

Herd 2: No pathogens

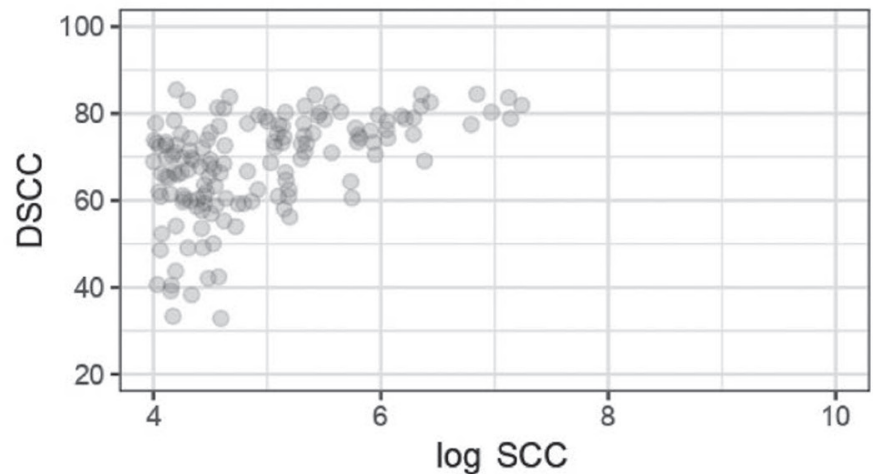

Figure 2. Differential SCC (DSCC) versus SCC for each of the pathogen groups included in this study based on bacterial culture testing. DSCC consists of the numbers of polymorphonuclear neutrophils (PMN), lymphocytes, and macrophages and describes the percentage of PMN and lymphocytes among these. 
Herd 1: Major pathogens

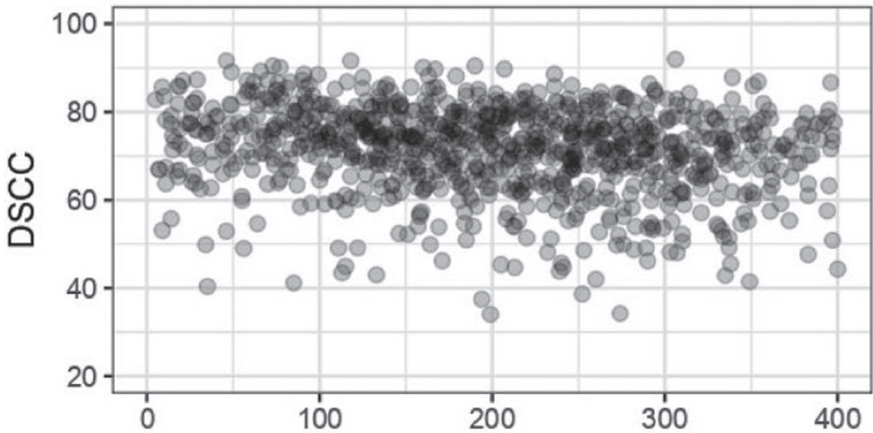

Herd 1: Other pathogens

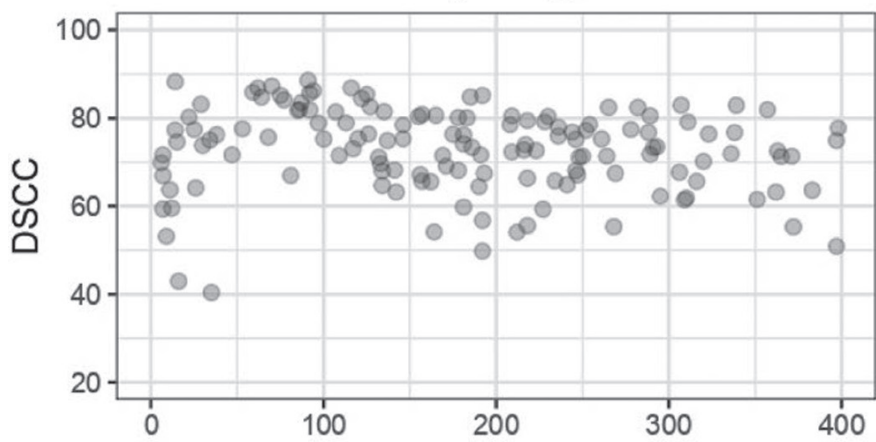

Herd 2: Major pathogens

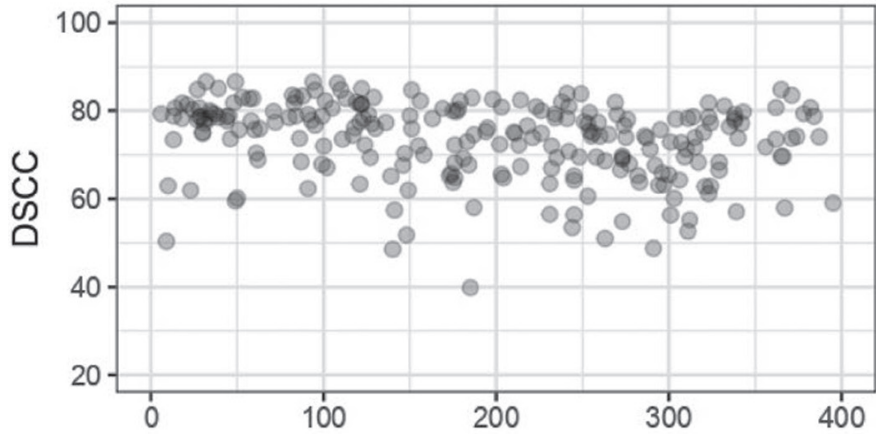

Herd 2: Other pathogens

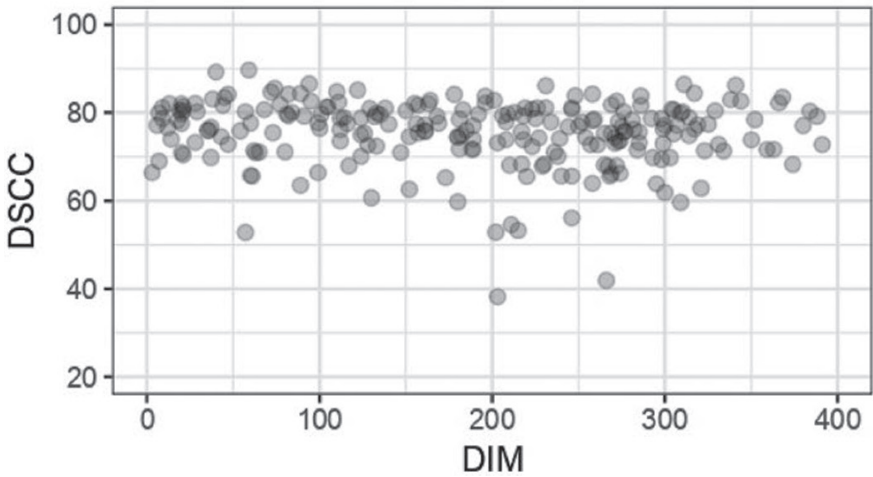

Herd 1: Minor pathogens

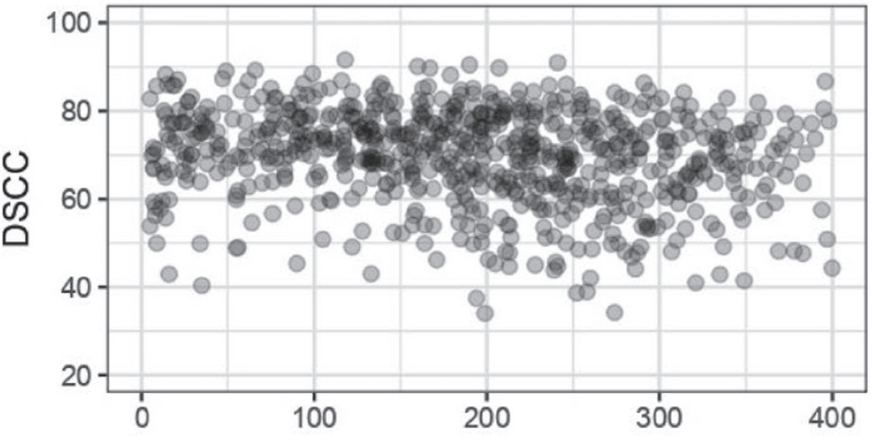

Herd 1: No pathogens

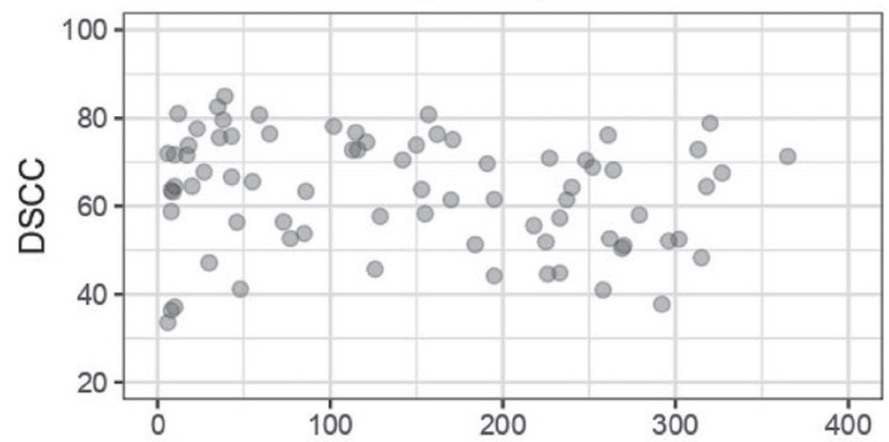

Herd 2: Minor pathogens

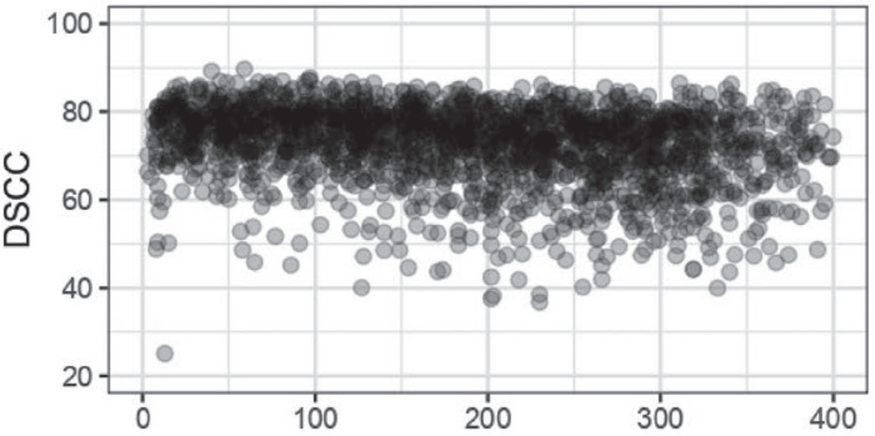

Herd 2: No pathogens

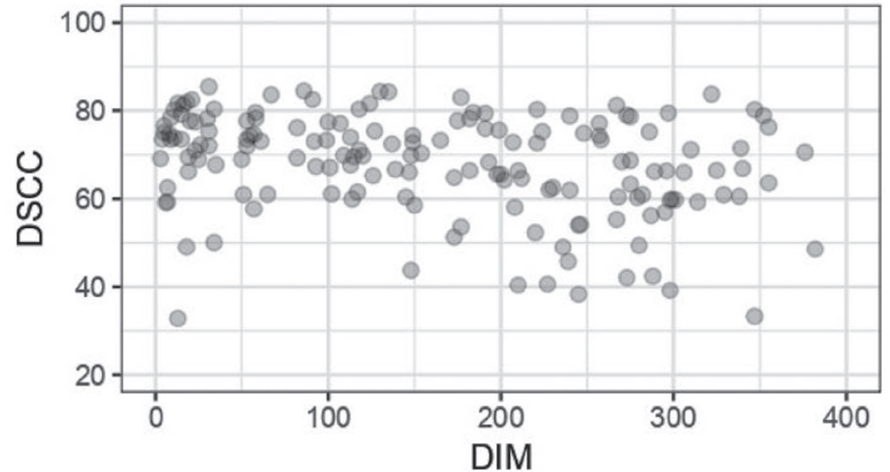

Figure 3. Differential SCC (DSCC) over DIM for each of the pathogen groups included in this study based on bacterial culture testing. DSCC consists of the numbers of polymorphonuclear neutrophils (PMN), lymphocytes, and macrophages and describes the percentage of PMN and lymphocytes among these. 
the AUC from the bootstrapping analysis with each of the 4 models, and their median values are presented in Table 4. All distributions overlapped, indicating that the models generally yielded similar results. However, there are differences among the distributions in some of the plots. This is the case for herd 1 with $\mathrm{BC}$ and major pathogens, where the baseline curve is clearly separate from the other curves. In other cases (as for herd 1 with

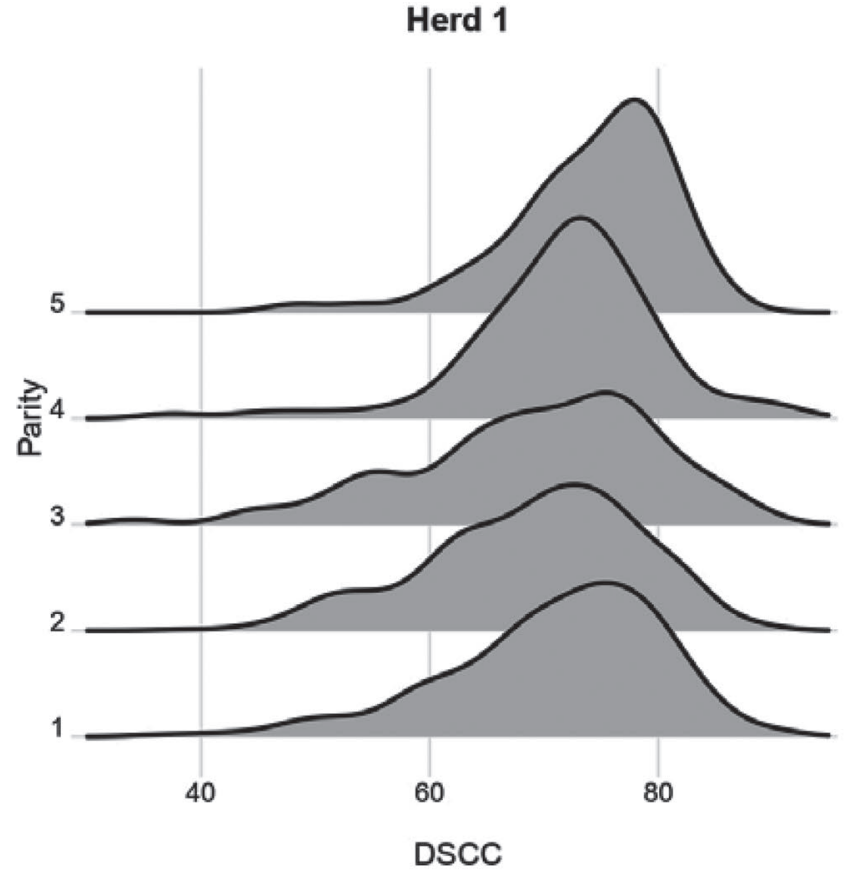

Herd 2

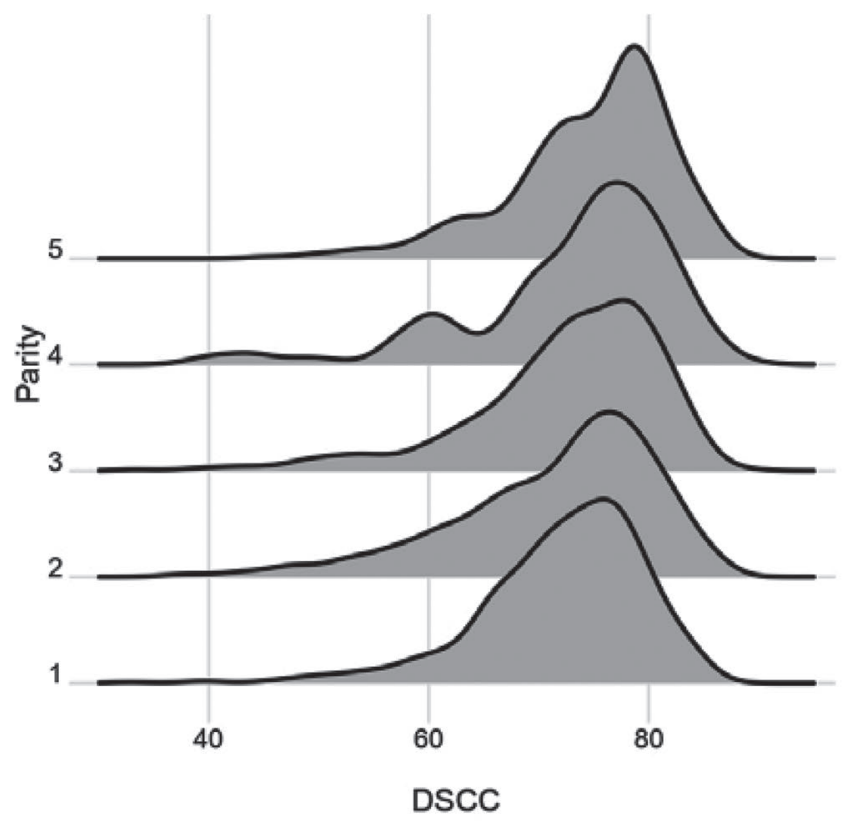

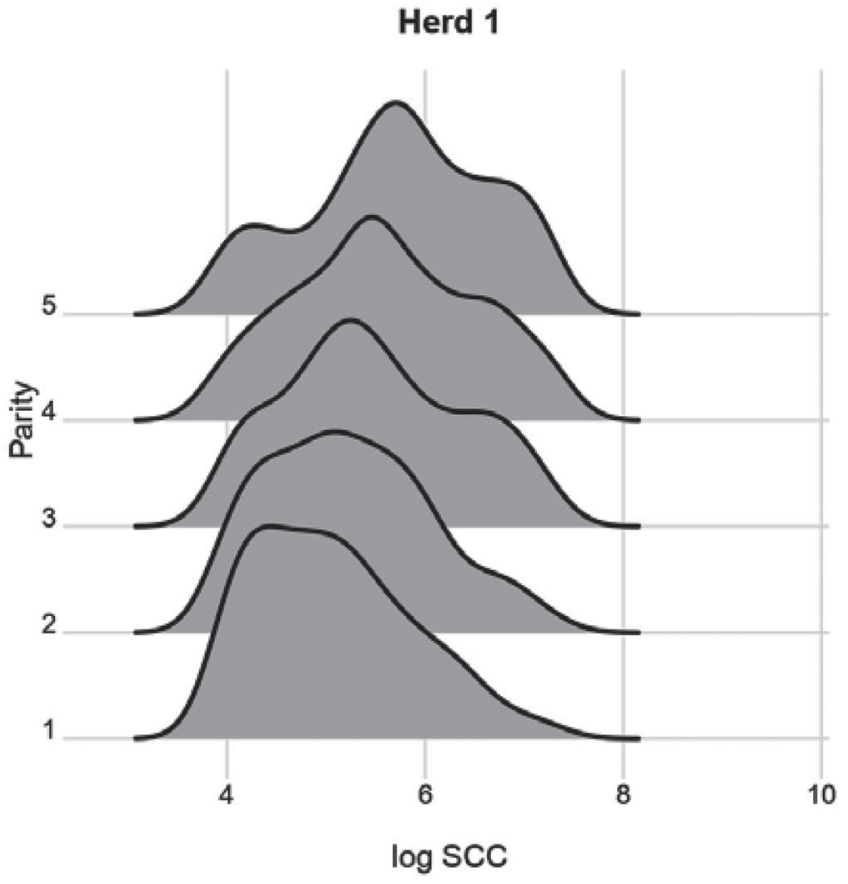

Herd 2

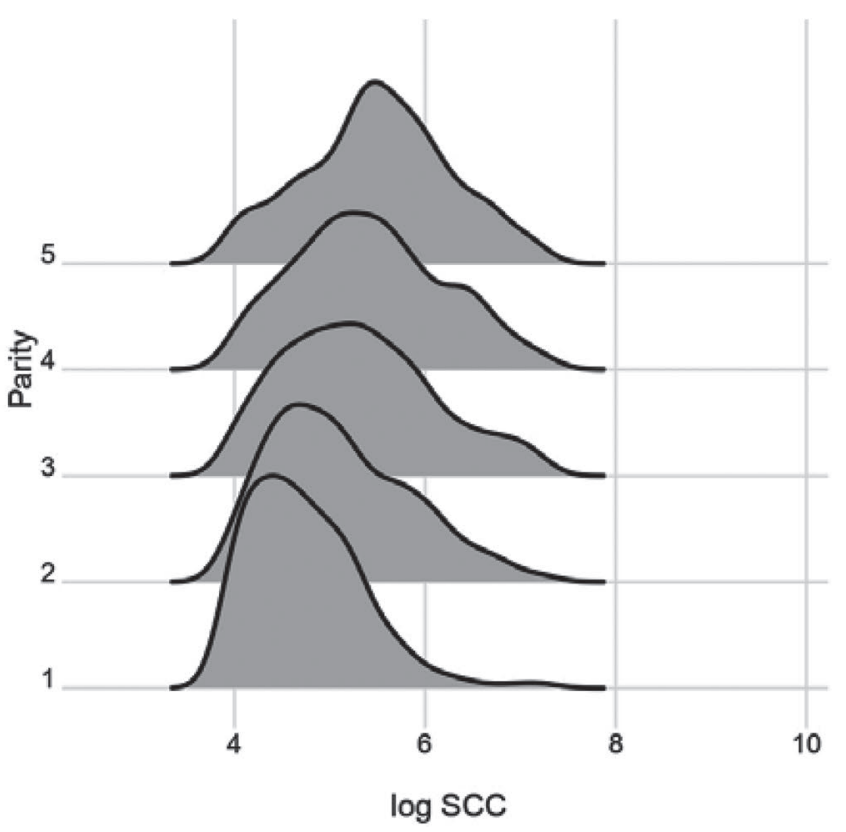

Figure 4. Smoothed density distributions for differential SCC (DSCC) and SCC in the 2 herds grouped by parity. DSCC consists of the numbers of polymorphonuclear neutrophils (PMN), lymphocytes, and macrophages and describes the percentage of PMN and lymphocytes among these. 
Herd 1

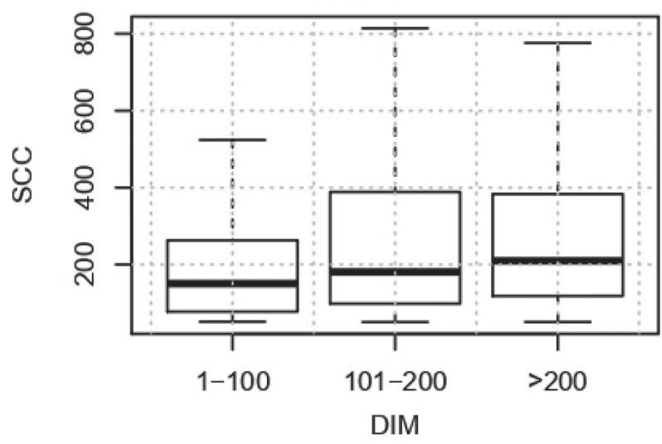

Herd 1

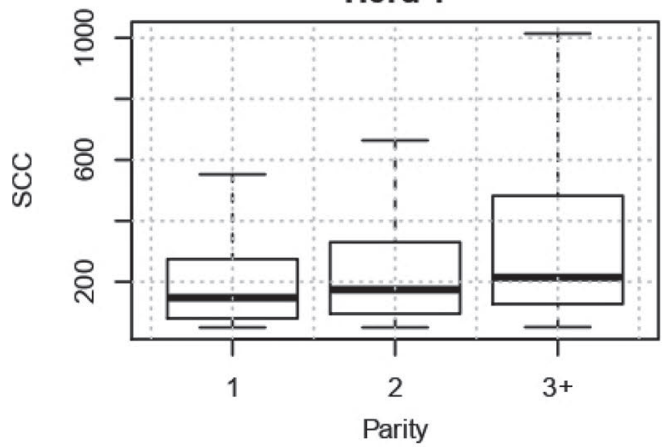

Herd 2

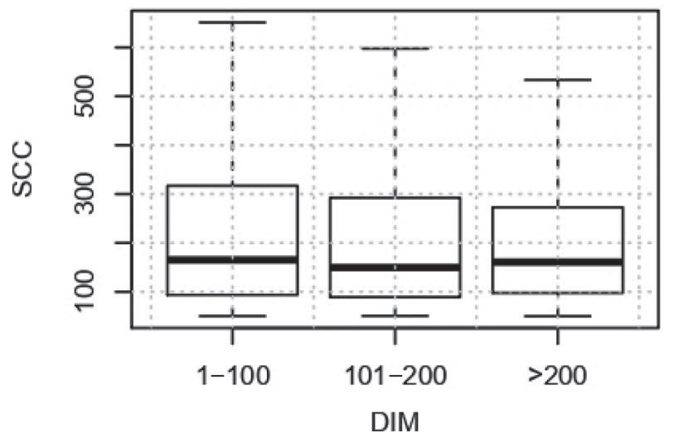

Herd 2

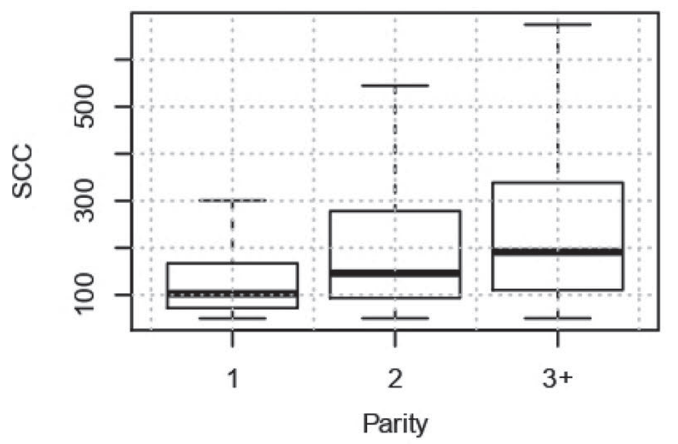

Herd 1

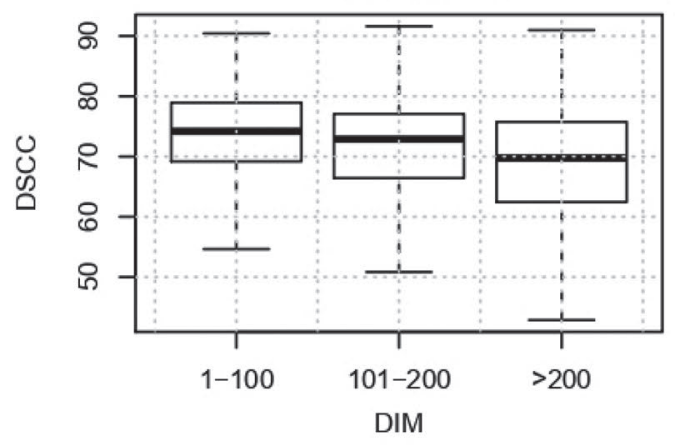

Herd 1

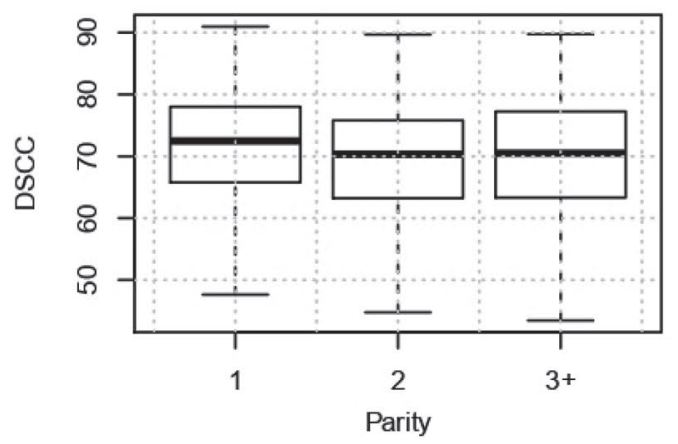

Herd 2

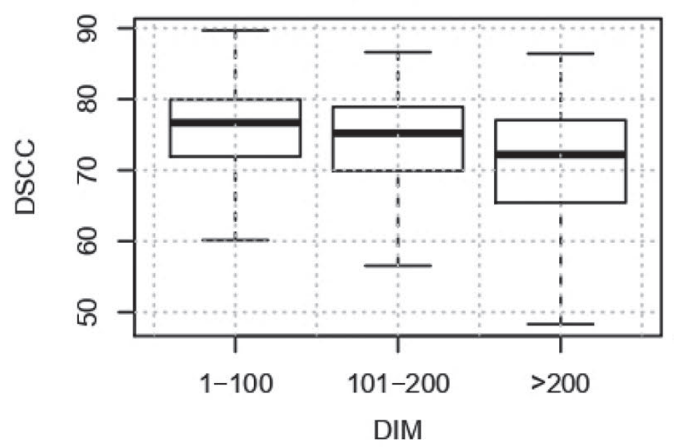

Herd 2

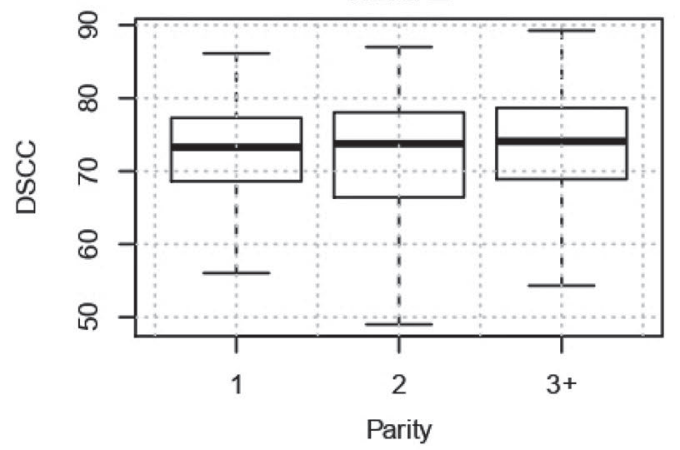

Figure 5. Boxplots showing the distributions of SCC and differential SCC (DSCC) for each herd, stratified by lactation stage and parity. Outliers are not shown. DSCC consists of the numbers of polymorphonuclear neutrophils (PMN), lymphocytes, and macrophages and describes the percentage of PMN and lymphocytes among these. The boxplots show the median and 25 and 75 percentiles of the data. The whiskers show the range of the data. 
$\mathrm{BC}$ and minor pathogens), all 4 curves are in almost the same position.

Supplemental Figures S1 to S4 (https://doi.org/10 .3168/jds.2019-16523) show the resulting ROC curves from the 250 bootstraps in each plot. Despite considerable variation among the repetitions for each model, there is a clear visual difference between the patterns of each of the 4 models for each scenario. For instance, for herd 2 with PCR and minor pathogens (Supplemental Figure S4), the model with either SCC or DSCC or both clearly improves the AUC compared with the baseline model. For other models, such as for herd 1 with BC and minor pathogens (Supplemental Figure S2), there is no apparent difference among the models.

\section{DISCUSSION}

This is the first comprehensive longitudinal study including entire dairy herds to evaluate DSCC as an additional indicator for IMI in dairy herds. Differential SCC is a newly available parameter indicating the combined proportion of PMN and lymphocytes in milk as a percentage of the total number of cells. Differential SCC therefore provides a more detailed picture of the actual

Table 3. Results from the final mixed-effect model with significant factors for explaining differential SCC

\begin{tabular}{|c|c|c|c|c|}
\hline \multirow[b]{2}{*}{ Item $^{2}$} & \multirow[b]{2}{*}{ Coefficient } & \multicolumn{2}{|c|}{$95 \% \mathrm{CI}$} & \multirow[b]{2}{*}{$P$-value ${ }^{3}$} \\
\hline & & Lower & Upper & \\
\hline \multicolumn{5}{|l|}{ Herd 1} \\
\hline \multicolumn{5}{|l|}{$\mathrm{BC}$} \\
\hline Intercept & 72.67 & 69.78 & 75.24 & \\
\hline Other pathogens & 8.37 & 2.09 & 14.53 & $<0.0001$ \\
\hline Minor pathogens & 1.86 & -0.58 & 4.33 & \\
\hline Major pathogens & 4.31 & 1.82 & 6.72 & \\
\hline DIM & -12.46 & -15.35 & -9.64 & $<0.0001$ \\
\hline $\mathrm{DIM}^{2}$ & & & & $\mathrm{NS}^{4}$ \\
\hline Parity 2 & -3.88 & -5.51 & -1.89 & $<0.05$ \\
\hline Parity $3+$ & -3.30 & -5.30 & -1.15 & \\
\hline \multicolumn{5}{|l|}{ PCR } \\
\hline Intercept & 75.81 & 73.80 & 77.76 & \\
\hline Other pathogens & -3.88 & -5.47 & -2.28 & $<0.0001$ \\
\hline Minor pathogens & -2.01 & -5.80 & 1.63 & \\
\hline Major pathogens & 2.93 & 1.89 & 3.90 & \\
\hline DIM & -13.86 & -16.83 & -10.67 & $<0.0001$ \\
\hline $\mathrm{DIM}^{2}$ & & & & NS \\
\hline Parity 2 & -3.64 & -5.38 & -2.01 & $<0.001$ \\
\hline Parity $3+$ & -3.29 & -5.44 & -1.08 & \\
\hline \multicolumn{5}{|l|}{ Herd 2} \\
\hline \multicolumn{5}{|l|}{$\mathrm{BC}$} \\
\hline Intercept & 72.48 & 70.91 & 74.28 & \\
\hline Other pathogens & 2.41 & -1.47 & 5.96 & $<0.0001$ \\
\hline Minor pathogens & 3.28 & 1.98 & 4.37 & \\
\hline Major pathogens & 3.31 & 1.70 & 4.91 & \\
\hline DIM & -14.73 & -19.57 & -10.09 & $<0.0001$ \\
\hline DIM $^{2}$ & & & & NS \\
\hline Parity 2 & -0.91 & -1.91 & 0.26 & $<0.0001$ \\
\hline Parity $3+$ & 1.46 & 0.30 & 2.61 & \\
\hline \multicolumn{5}{|l|}{ PCR } \\
\hline Intercept & 74.61 & 73.40 & 75.81 & \\
\hline Other pathogens & -0.03 & -0.64 & 0.63 & $<0.0001$ \\
\hline Minor pathogens & 2.53 & 1.78 & 3.21 & \\
\hline Major pathogens & 3.85 & 3.00 & 4.66 & \\
\hline DIM & -10.81 & -12.40 & -9.33 & $<0.0001$ \\
\hline $\mathrm{DIM}^{2}$ & -1.35 & -2.39 & -0.26 & NS \\
\hline Parity 2 & 0.98 & -0.40 & 2.33 & $<0.0001$ \\
\hline Parity 3+ & 74.61 & 73.40 & 75.81 & \\
\hline
\end{tabular}

${ }^{1}$ Differential SCC consists of the numbers of polymorphonuclear neutrophils (PMN), lymphocytes, and macrophages and describes the percentage of PMN and lymphocytes among these.

${ }^{2} \mathrm{DIM}$ and $\mathrm{DIM}^{2}$ are normalized.

${ }^{3} P$-values were estimated in the backward elimination procedure. The $P$-value for pathogens is for the inclusion of all groups. The same is true for the $P$-value for parities. $P$-values represent all pathogens and parities.

${ }^{4}$ Not significant. 
Table 4. The results from comparing mixed-effect models for IMI status with DSCC ${ }^{1}+$ SCC against a model with only SCC, a model with only DSCC, and a baseline model

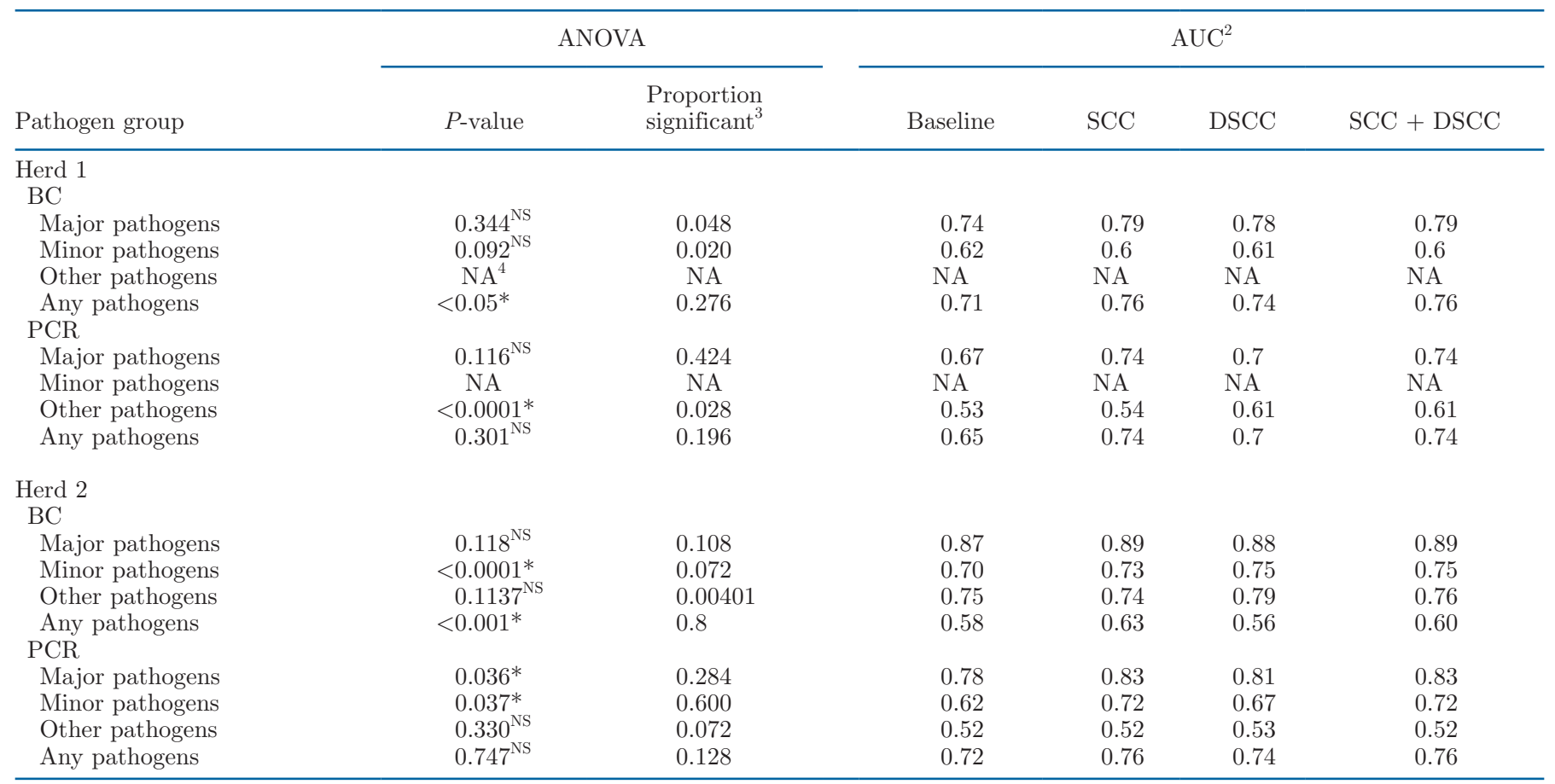

${ }^{1}$ Differential SCC (DSCC) consists of the numbers of polymorphonuclear neutrophils (PMN), lymphocytes, and macrophages and describes the percentage of PMN and lymphocytes among these.

${ }^{2} \mathrm{AUC}=$ area under the curve. The 4 columns show the median of the distribution of AUC found in the bootstrap analysis for baseline models and models with SCC, DSCC, and SCC + DSCC. All SCC values are given in 1,000 cells $/ \mathrm{mL}$.

${ }^{3}$ Shows the proportion of the 250 bootstrap iterations that resulted in a statistically significant value.

${ }^{4}$ Not available.

*Statistical significance on the $5 \%$ level.

immune response than was previously possible. The objective of this study was to assess the characteristics of DSCC and evaluate whether DSCC would improve the indication of IMI when used together with SCC compared with a situation in which only SCC is used. Using BC, DSCC contributed significantly to indicating any pathogens in both herds as well as minor pathogens in herd 2 when SCC was already known. This means that indication of IMI is significantly improved when using both SCC and DSCC compared with using only SCC when considering IMI in general or minor pathogens in herd 2. Using PCR on cow-composite samples, DSCC contributed significantly to indicating IMI with major and other pathogens in herd 1 and major and minor pathogens in herd 2. However, out of the mixed-effect models for which DSCC was significant for indicating IMI, only small proportions were significant in the bootstrap tests (Table 4 ). The most robust result was obtained when considering any pathogens using $\mathrm{BC}$ in both herds.

We studied cows in 2 herds over 1 yr and sampled them on a monthly basis to reflect the sampling in milk recording schemes, similar to the intended use of DSCC records. We collected cow-composite samples and determined the IMI status using PCR as per the normal procedure for cow-composite samples in Denmark, which is far more common than testing quarter foremilk samples. Because the test sensitivity is generally lower for cow-composite samples compared with quarter foremilk samples (Reyher and Dohoo, 2011), we collected quarter foremilk samples and analyzed them with $\mathrm{BC}$ to evaluate the utility of DSCC measured on the cow-composite samples for indicating IMI. Bacterial culture is considered to be the reference standard for diagnosing IMI (National Mastitis Council, 2004).

Differential SCC was affected by DIM and parity, but in a different way than SCC (Figure 5). For instance, SCC increases over the lactation (although this was seen only in herd 1 in this study), whereas DSCC decreased with increasing DIM. A dilution effect has been suggested to explain this increase in SCC (Green et al., 2006; Græsbøll et al., 2016). Differential SCC seems to be less affected by the dilution effect because it clearly follows the lactation curve. When comparing stability 
over parities, DSCC is more stable than SCC (Figures 4 and 5).

A positive correlation was observed between $\mathrm{SCC}$ and DSCC (Figure 2), as previously suggested by others (e.g., Schwarz et al., 2011; Damm et al., 2017), indicating an increased DSCC following infection as with SCC. This was supported by the results of the mixed-effect models (Table 3), in which infection with a pathogen group was a significant predictor for DSCC.
However, Figure 2 clearly shows that a large proportion of samples had high DSCC counts and low SCC counts, which may indicate that the 2 measures reflect different phases of the infection, as also suggested by Aref et al. (2018). To investigate this further, it is necessary to understand the behavior of DSCC in relation to SCC during the different stages of IMI. This will help us understand how to use these parameters simultaneously - for instance, to indicate an early infection stage
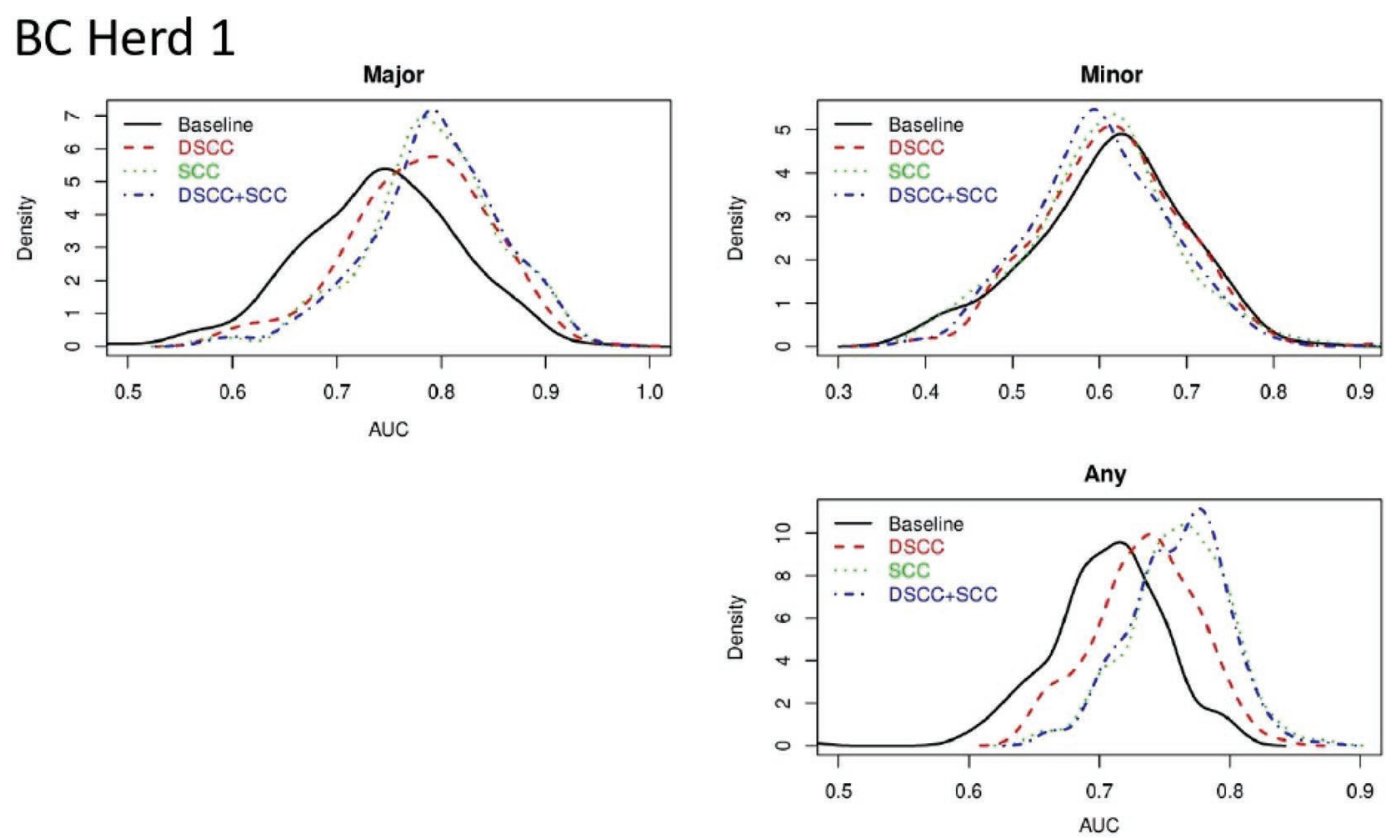

\section{BC Herd 2}
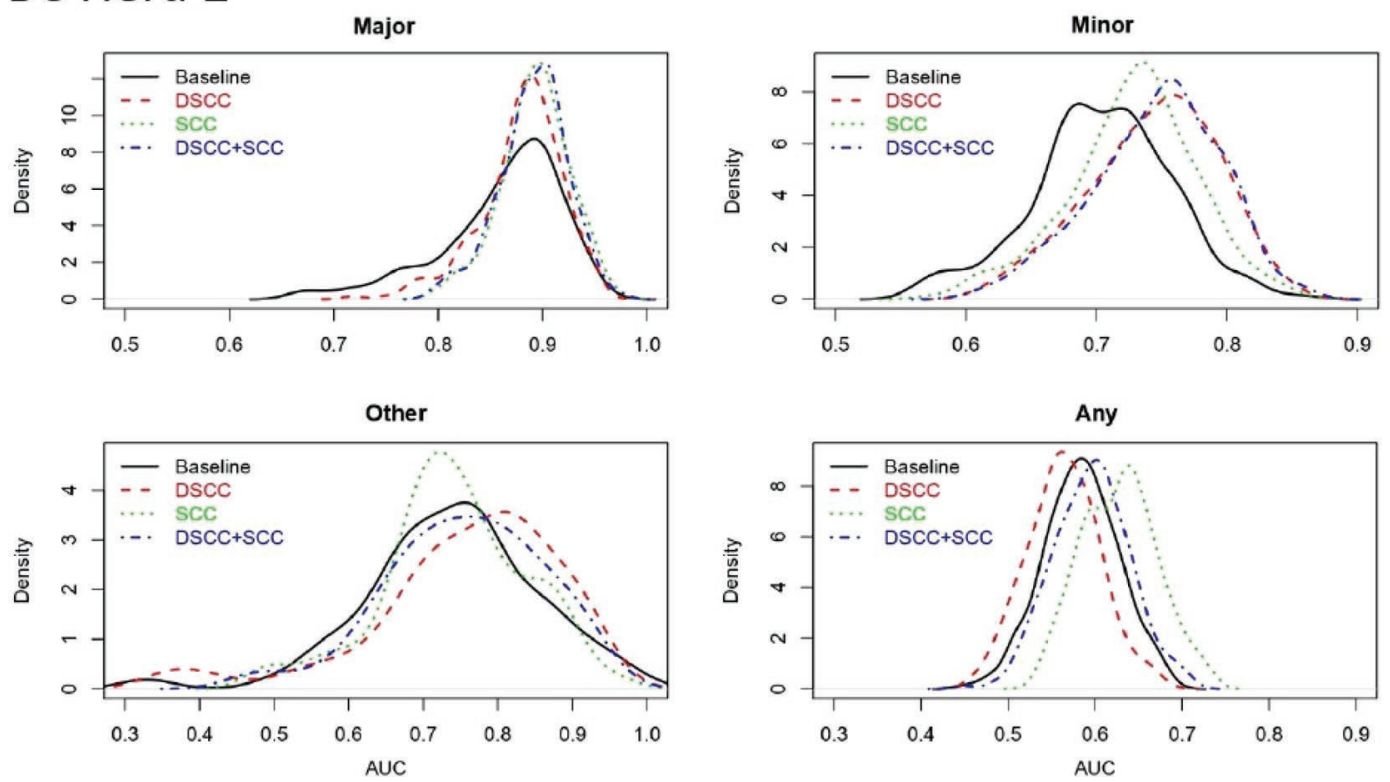

Figure 6. Area under the curve (AUC) distributions for the receiver operating characteristic curves resulting from the bootstrap analysis using bacterial culture (BC) for detecting pathogens. Differential SCC (DSCC) consists of the numbers of polymorphonuclear neutrophils (PMN), lymphocytes, and macrophages and describes the percentage of PMN and lymphocytes among these. 


\section{PCR Herd 1}
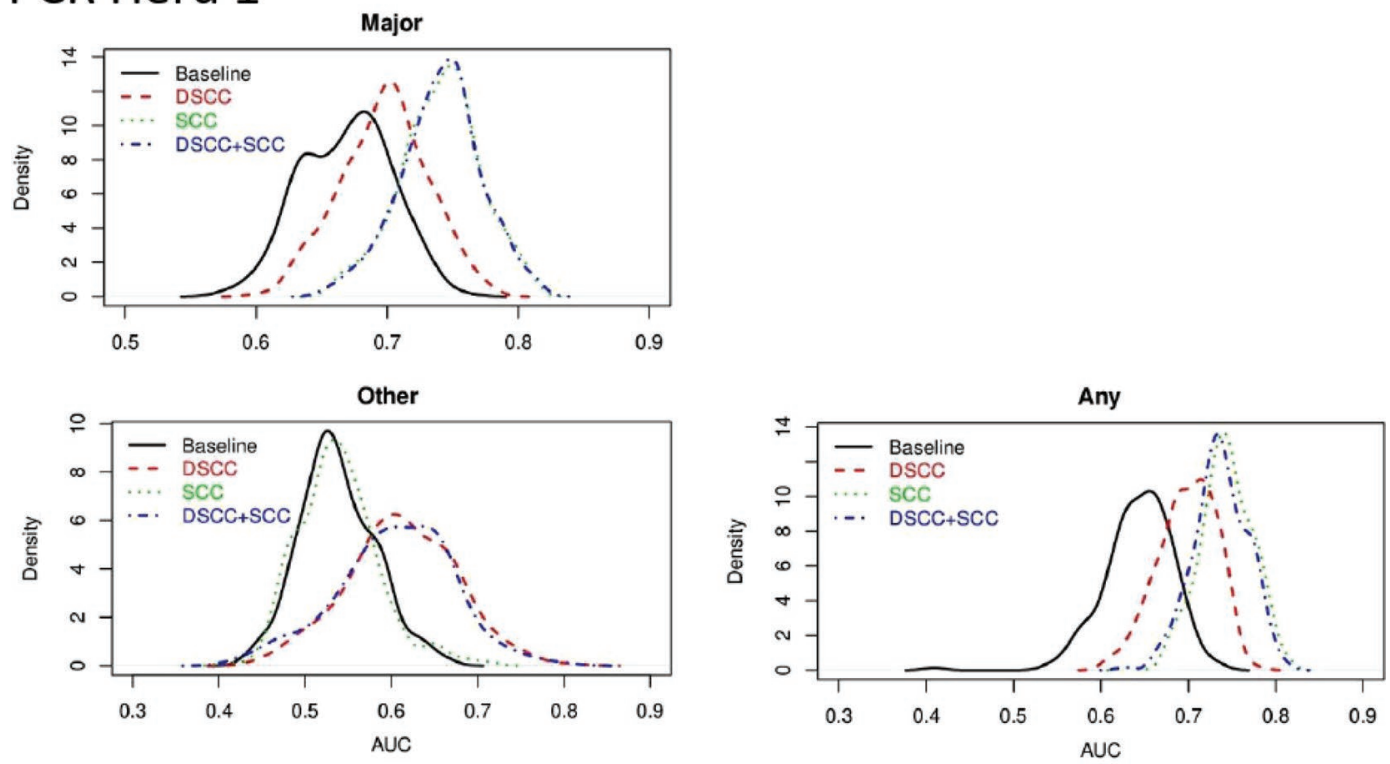

\section{PCR Herd 2}
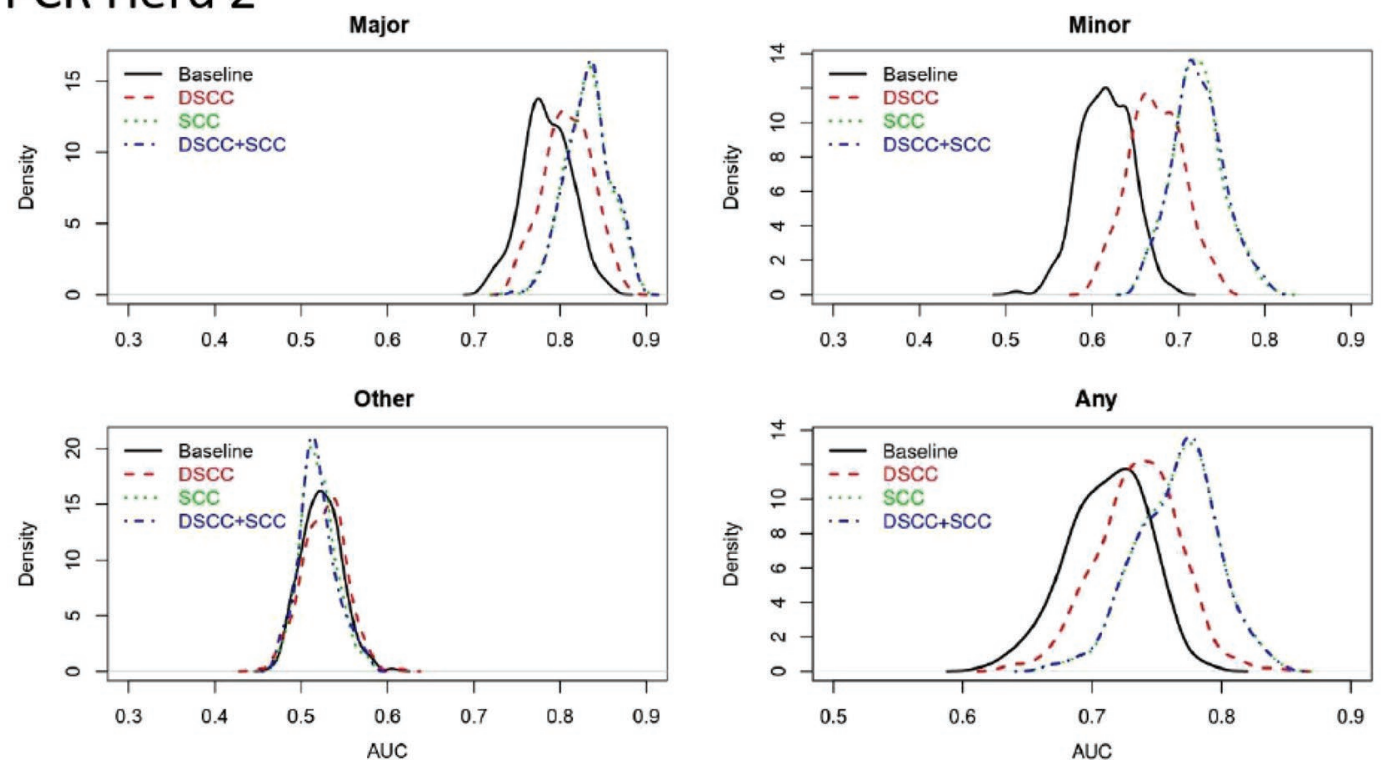

Figure 7. Area under the curve (AUC) distributions for the receiver operating characteristic curves resulting from the bootstrap analysis using PCR for detecting pathogens. DSCC consists of the numbers of polymorphonuclear neutrophils (PMN), lymphocytes, and macrophages and describes the percentage of PMN and lymphocytes among these.

or a chronic infection. This was previously described by Wall et al. (2018) in a study with 20 dairy cows but should be investigated further on a larger scale and under field conditions to fully determine this relationship. Furthermore, it will be interesting to calculate the sensitivity and specificity for using SCC and DSCC for predicting IMI using different cutoffs. Using DSCC together with SCC may improve the sensitivity and specificity of indicating IMI and its cost-effectiveness compared with using only SCC. These issues should be addressed in future studies to investigate the added value of using DSCC in more detail.

In this study, DSCC contributed significantly to indicating any pathogens when using BC in both herds. This reflects a realistic situation in which a farmer could add DSCC routinely to indicate IMI, as is currently done with SCC, regardless of the pathogen. However, this was not found to be the case when using the composite PCR samples. This could likely be due to the decrease in positive samples found when using PCR, where the 
number of negative samples increased from $5 \%$ when using BC in herd 1 to $37 \%$ when using PCR. Similarly, in herd 2 the number of negative samples increased from $8 \%$ when using $\mathrm{BC}$ to $51 \%$ when using PCR. A cow-composite sample is diluted by uninfected quarters of the same cow, which may affect the sensitivity of the test (Reyher and Dohoo, 2011). We also observed that when using $\mathrm{BC}$ for testing, DSCC was associated with the indication of minor pathogens in herd 2. The role of minor pathogens in causing IMI and the subsequent effect on the SCC and production have been extensively debated in the literature (e.g., Harmon, 1994; Pyörälä and Taponen, 2009; Schukken et al., 2009; De Vliegher et al., 2012), and it is unclear when minor pathogens constitute a problem due to the highly variable pathogenicity within this group. A recent study showed that minor pathogens can impair the performance of dairy cows, for example, causing production loss (Heikkilä et al., 2018). Nonetheless, because the presence of minor pathogens may not always be associated with increased SCC (e.g., Figure 2), DSCC might be a useful addition for indicating problems with minor pathogens. For instance, an increase in DSCC while SCC is still low could indicate an early stage of IMI (Schwarz et al., 2011), and this might be sufficient to clear a minor pathogen infection. In this case, it might not be necessary for the farmer to intervene because the animal could clear the IMI itself. If IMI is not cleared and the problem persists, an intervention (treatment with antibiotics) can be implemented. This could facilitate the prudent use of antibiotics as treatment could be targeted at animals that need it while avoiding antibiotic use for animals that can spontaneously clear the infection. A large part of the antibiotics used are for dry cow therapy; therefore, future studies could also be focused on the test characteristics of DSCC in relation to selective dry cow therapy. Specifically, it may be useful to include information over time (e.g., on new or chronic infections) to further explore more opportunities to use DSCC. Future research should also focus on the behavior of SCC and DSCC for uninfected and infected quarters - for example, if the extreme values in the upper and lower tails of SCC and DSCC, respectively, arise from the same or different infection stages (Figure 4).

In the bootstrap analysis (Table 4), we took a closer look at the performance of the models in terms of indicating IMI when including DSCC. In general, when using BC, the ROC test showed a significant effect of including DSCC in 28\% of the cases for herd 1 and $80 \%$ of the cases for herd 2. However, when looking at the individual pathogen groups, the proportion of cases where DSCC contributed significantly was rather low. This indicates that DSCC can be useful in indicat- ing any pathogens but less so when looking for specific pathogen groups. Differential SCC was still highly significant for indicating minor pathogens in herd 2, but this herd had a high prevalence of these pathogens (Table 2) and the performance of DSCC could therefore be affected by the number of samples. It is also worth noting that herd 1 had fewer cows than herd 2, and fewer data were therefore obtained from this herd.

When comparing the AUC between a baseline model with SCC and a baseline model with DSCC, there was variation in which one had the highest AUC. Furthermore, for indicating infection in general (any pathogens), using DSCC did not increase the AUC in our analyses compared with when only SCC was used. However, DSCC was still significant for detection of IMI in those cases. In cases where the AUC is already high, it can only increase incrementally. Therefore, when the AUC of the model with SCC was already high, the improvement when including DSCC was not as obvious (Figures 6 and 7), though it was still statistically significant in some cases (Table 4). However, in some cases (as for herd 1 with BC and minor pathogens), the baseline curve was slightly higher than all other curves. This indicates that with sparse data, adding either SCC or DSCC or both to this model could result in overfitting, causing a model trained on $80 \%$ of the data to perform poorly on the last $20 \%$ of the data.

It is important to note that we omitted all the records from cows with low or very high SCC, which were outside the performance range of the Fossomatic 7 DC. Therefore, we did not have many cows that were uninfected, which is likely to have made this evaluation more rigorous than necessary and probably underestimated the potential of using DSCC. However, we chose this as the most appropriate way to conduct the study. In a real-life situation, SCC information on healthy cows will also be available and useful. Including healthy cows (with SCC $<50,000$, although they could also be infected) would likely allow for better identification of infected cows because the healthy group would be larger. In this case, DSCC would not be available, but a low DSCC value could be assumed. Another challenge related to the data is that the pathogen groups are not mutually exclusive. Thus, for instance, many records with minor pathogens were excluded from the analysis of the minor pathogen group with $\mathrm{BC}$ in herd 1 because these cows were also infected with major pathogens. This could be avoided with a quarter-level analysis. Nevertheless, in reality, SCC and DSCC are available at cow level and hence the analyses here were also at cow level.

This study was limited to investigate 2 Danish dairy farms only, but to a detailed level. However, these herds represent a major proportion of Danish farms in the 
sense that about $75 \%$ of Danish farms do not use milking robots and almost all are freestall farms (Barkema et al., 2015; Michael Farre, chief consultant, SEGES, Aarhus, Denmark; personal communication). However, because we do not have data on the prevalence of pathogens in general, we are not able to compare the farms in this regard. Farms have different distributions of pathogens causing IMI. If DSCC reacts differently to the different pathogens causing IMI, then the use of DSCC as an additional indicator for IMI must be investigated in more herds to evaluate its potential.

The DSCC was correlated with IMI and could even contribute significantly to improve indication of IMI when SCC was already known in some cases, even though the difference seems to be small. However, the economic benefit of using DSCC in addition to SCC is yet to be quantified, which could be done using, for instance, bioeconomic simulation models. This will also depend on, among other factors, the additional expenses for the DSCC result, which pathogens are causing IMI within a specific herd, the prevalence of pathogens in the herd, and how DSCC is being used, for instance, to select cows for dry cow therapy, for lactational treatment of subclinical cases, or for culling. Furthermore, we did not consider the potential of using repeated measurements of SCC or DSCC, for instance, to indicate chronicity. We plan to explore these questions further in future studies.

\section{CONCLUSIONS}

Differential SCC is a newly available parameter for measuring IMI in milk from dairy cows. In this study, we explored the factors affecting DSCC and the potential of using DSCC in addition to SCC for indicating IMI. Differential SCC is significantly affected by the IMI status, DIM, and parity of the cow. Therefore, these factors must be taken into account when interpreting DSCC in relation to IMI, similar to SCC. We found that DSCC could contribute statistically for indicating IMI with any pathogens when using $\mathrm{BC}$ of quarter foremilk samples even when SCC was already known. This means that there is an extra improvement of using DSCC in addition to SCC for indicating IMI (e.g., allowing the detection of more infected cows as such). When using PCR on cow-composite samples, the added effect of using DSCC was generally limited. We also found that DSCC was statistically significant for indicating IMI with minor pathogens in herd 2 when using BC even when SCC was already known. We suggest that future studies explore the value and economic potential of using DSCC to indicate IMI.

\section{ACKNOWLEDGMENTS}

We thank the participating farmers and the teams from SEGES, Registrerings- og Ydelseskontrol (Skejby, Denmark) and Foss (Hillerød, Denmark) for helping with data acquisition and Karen Schlez and Tobias Eisenberg at LHL (Gießen, Germany) for bacterial culture and identification of pathogens. This project was funded by the Green Development and Demonstration Program (GUDP) under the Danish Directorate for Food, Fisheries and Agriculture (Copenhagen, Denmark) grant no. 34009-15-0918 (EMCo-MAST project). Foss Analytical A/S funded their own participation in this project, including providing SCC and differential SCC results. The study design, data collection, sample testing, and data analysis and writing process were funded by GUDP.

\section{REFERENCES}

Aref, N. M., A. S. Sayed, A. M. Zahran, G. A. Abdelaal, and E. A. Nasser. 2018. Flow cytometric analysis of somatic cells and oxidant/antioxidant profile in dairy cows with subclinical mastitis. Bulg. J. Vet. Med. 21:347-357. https://doi.org/10.15547/bjvm .1089 .

Barkema, H. W., M. A. von Keyserlingk, J. P. Kastelic, T. J. Lam, C. Luby, J. P. Roy, S. J. LeBlanc, G. P. Keefe, and D. F. Kelton. 2015. Invited review: Changes in the dairy industry affecting dairy cattle health and welfare. J. Dairy Sci. 98:7426-7445. https://doi .org/10.3168/jds.2015-9377.

Bates, D., M. Mächler, B. Bolker, and S. Walker. 2015. Fitting linear mixed-effects models using lme4. J. Stat. Softw. 67:1-48. https:// doi.org/10.18637/jss.v067.i01.

Bennedsgaard, T. W., L. Svennesen, and I. C. Klaas. 2016. Test characteristics of the qPCR test Mastit 4 to identify major pathogens in spiked and originally infected milk samples. Pages $180-181$ in Proc. 55th Ann. Mtg. Natl. Mastitis Counc., Glendale, AZ. National Mastitis Council, Verona, WI.

Damm, M., C. Holm, M. Blaabjerg, M. N. Bro, and D. Schwarz. 2017. Differential somatic cell count-A novel method for routine mastitis screening in the frame of Dairy Herd Improvement testing programs. J. Dairy Sci. 100:4926-4940. https://doi.org/10.3168/ jds.2016-12409.

De Vliegher, S., L. F. Fox, S. Piepers, S. McDougall, and H. W. Barkema. 2012. Invited review: Mastitis in dairy heifers: Nature of the disease, potential impact, prevention, and control. J. Dairy Sci. 95:1025-1040. https://doi.org/10.3168/jds.2010-4074.

DeLong, E. R., D. M. DeLong, and D. L. Clarke-Pearson. 1988. Comparing the areas under two or more correlated receiver operating characteristic curves: A nonparametric approach. Biometrics 44:837-845. https://doi.org/10.2307/2531595.

Græsbøll, K., C. Kirkeby, S. S. Nielsen, T. Halasa, N. Toft, and L. E. Christiansen. 2016. Models to estimate lactation curves of milk yield and somatic cell count in dairy cows at the herd level for the use in simulations and predictive models. Front. Vet. Sci. 3:115. https://doi.org/10.3389/fvets.2016.00115.

Green, L. E., Y. H. Schukken, and M. J. Green. 2006. On distinguishing cause and consequence: Do high somatic cell counts lead to lower milk yield or does high milk yield lead to lower somatic cell count. Prev. Vet. Med. 76:74-89. https://doi.org/10.1016/j .prevetmed.2006.04.012.

Halasa, T., K. Huijps, O. Østerås, and H. Hogeveen. 2007. Economic effects of bovine mastitis and mastitis management: A review. Vet. Q. 29:18-31. https://doi.org/10.1080/01652176.2007.9695224. 
Harmon, R. J. 1994. Physiology of mastitis and factors affecting somatic cell counts. J. Dairy Sci. 77:2103-2112. https://doi.org/10 .3168/jds.S0022-0302(94)77153-8.

Heikkilä, A. M., E. Liski, S. Pyörälä, and S. Taponen. 2018. Pathogen-specific production losses in bovine mastitis. J. Dairy Sci. 101:9493-9504. https://doi.org/10.3168/jds.2018-14824.

IDF (International Dairy Federation). 2013. Guidelines for the use and interpretation of bovine milk somatic cell count. Bull. no. 466/2013. IDF, Brussels, Belgium.

Jones, G. M. 2009. Guidelines for using the DHI automatic cell count program. Pub. no. 404-228. Virginia Coop. Extension, Blacksburg, VA.

Kirkeby, C., L. Zervens, N. Toft, D. Schwarz, M. Farre, S. Hechinger, and T. Halasa. 2019. Transmission dynamics of Staphylococcus aureus within two Danish dairy cattle herds. J. Dairy Sci. 102:1428 1442. https://doi.org/10.3168/jds.2018-15106.

National Mastitis Council. 2004. Microbiological Procedures for Use in the Diagnosis of Bovine Udder Infection and Determination of Milk Quality. 4th ed. NMC, Verona, WI.

Oliver, S. P., M. J. Lewis, B. E. Gillespie, S. P. Oliver, M. J. Lewis, B. E. Gillespie, H. H. Dowlen, E. Jaenicke, and R. K. Roberts. 2004. Microbiological procedures for the diagnosis of bovine udder infection and determination of milk quality. National Mastitis Council, Verona, WI.

Pilla, R., M. Malvisi, G. G. M. Snel, D. Schwarz, S. König, C. P. Czerny, and R. Piccinini. 2013. Differential cell count as an alternative method to diagnose dairy cow mastitis. J. Dairy Sci. 96:1653-1660. https://doi.org/10.3168/jds.2012-6298.

Pillai, S. R., E. Kunze, L. M. Sordillo, and B. M. Jayarao. 2001. Application of differential inflammatory cell count as a tool to monitor udder health. J. Dairy Sci. 84:1413-1420. https://doi.org/10.3168/ jds.S0022-0302(01)70173-7.

Pinheiro, J., D. Bates. S. DebRoy, D. Sarkar, and R Core Team. 2018. nlme: Linear and nonlinear mixed effects models. R package version 3.1-137. Accessed Aug. 1, 2019. https://CRAN.R-project . org $/$ package $=$ nlme.

Pyörälä, S. 2003. Indicators of inflammation in the diagnosis of mastitis. Vet. Res. 34:565-578. https://doi.org/10.1051/vetres:2003026.

Pyörälä, S., and S. Taponen. 2009. Coagulase-negative staphylococciEmerging mastitis pathogens. Vet. Microbiol. 134:3-8. https://doi .org/10.1016/j.vetmic.2008.09.015.

R Core Team. 2015. R: A language and environment for statistical computing. Accessed Aug. 1, 2019. https://www.r-project.org/.

Reneau, J. K. 1986. Use of dairy herd improvement somatic cell counts in mastitis control. J. Dairy Sci. 69:1708-1720. https://doi.org/10 .3168/jds.S0022-0302(86)80590-2.

Reyher, K. K., and I. R. Dohoo. 2011. Diagnosing intramammary infections: Evaluation of composite milk samples to detect intramammary infections. J. Dairy Sci. 94:3387-3396. https://doi.org/10 $.3168 /$ jds.2010-3907.

Robin, X., N. Turck, A. Hainard, N. Tiberti, F. Lisacek, J. C. Sanchez, and M. Müller. 2011. pROC: An open-source package for R and
$\mathrm{S}+$ to analyze and compare ROC curves. BMC Bioinformatics 12:77. https://doi.org/10.1186/1471-2105-12-77.

Schepers, A. J., T. J. Lam, Y. H. Schukken, J. B. Wilmink, and W. J. Hanekamp. 1997. Estimation of variance components for somatic cell counts to determine thresholds for uninfected quarters. J. Dairy Sci. 80:1833-1840. https://doi.org/10.3168/jds.S0022 -0302(97)76118-6.

Schukken, Y. H., R. N. González, L. L. Tikofsky, L. F. Schulte, C. G. Santisteban, F. L. Welcome, G. J. Bennett, M. J. Zurakowski, and R. N. Zadoks. 2009. CNS mastitis: Nothing to worry about? Vet. Microbiol. 134:9-14. https://doi.org/10.1016/j.vetmic.2008 .09 .014 .

Schukken, Y. H., D. J. Wilson, F. Welcome, L. Garrison-Tikofsky, and R. N. Gonzalez. 2003. Monitoring udder health and milk quality using somatic cell count. Vet. Res. 34:579-596. https://doi.org/10 .1051/vetres:2003028.

Schwarz, D., U. S. Diesterbeck, K. Failing, S. Konig, K. Brugemann, M. Zschock, W. Wolter, and C.-P. Czerny. 2010. Somatic cell counts and bacteriological status in quarter foremilk samples of cows in Hesse, Germany-A longitudinal study. J. Dairy Sci 93:5716-5728. https://doi.org/10.3168/jds.2010-3223.

Schwarz, D., U. S. Diesterbeck, S. König, K. Brügemann, K. Schlez, M. Zschöck, W. Wolter, and C. P. Czerny. 2011. Flow cytometric differential cell counts in milk for the evaluation of inflammatory reactions in clinically healthy and subclinically infected bovine mammary glands. J. Dairy Sci. 94:5033-5044. https://doi.org/10 $.3168 /$ jds.2011-4348.

Sordillo, L. M., and K. L. Streicher. 2002. Mammary gland immunity and mastitis susceptibility. J. Mammary Gland Biol. Neoplasia 7:135-146. https://doi.org/10.1023/A:1020347818725.

von Keyserlingk, M. A. G., J. Rushen, A. M. de Passillé, and D. M. Weary. 2009. Invited review: The welfare of dairy cattle-Key concepts and the role of science. J. Dairy Sci. 92:4101-4111. https:// doi.org/10.3168/jds.2009-2326.

Wall, S. K., O. Wellnitz, R. M. Bruckmaier, and D. Schwarz. 2018. Differential somatic cell count in milk before, during and after lipopolysaccharide- and lipoteichoic-acid-induced mastitis in dairy cows. J. Dairy Sci. 101:5362-5373. https://doi.org/10.3168/jds .2017-14152

\section{ORCIDS}

C. Kirkeby (ำ https://orcid.org/0000-0001-9292-5526

D. Schwarz @ https://orcid.org/0000-0002-7108-8754

M. Farre (ํ) https://orcid.org/0000-0002-8252-964X

S. S. Nielsen (1) https://orcid.org/0000-0003-2417-0787

T. Halasa @ https://orcid.org/0000-0003-1112-0254 